\title{
Complicating Medieval Anti-Semitism: The Role of Class in Two Tales of Christian Violence against Jews
}

DIANE WOLFTHAL Rice University

\begin{abstract}
Miri Rubin justly concluded that "most remaining traces" of medieval atrocities against Jews "represent the position of Christian authorities-chroniclers, preachers, town officials-who were almost always writing in defence or celebration of the events." The exceptions to this rule, however, are illuminating. This article explores images produced for Christians that condemn Christian acts of violence against Jews. Although these are few in number, their existence complicates our understanding of medieval anti-Semitism. The first part of the essay investigates an episode in a fourteenth-century French chronicle, the pillage of the Jews of Paris in 1380. The second part examines depictions of the fable of the murdered Jew, which date from the late thirteenth through the fifteenth century. Both narratives-one drawn from a historical event, the other grafted onto an ancient fable-portray the Jew as the innocent victim and the Christian as the treacherous assailant. In so doing, they reverse the betterknown paradigm of the Jew as the evil aggressor who attacks innocent Christian boys or the consecrated host. This essay considers the circumstances that enabled some Christians to view with sympathy the figure of a vulnerable, attacked Jew and proposes that sometimes class interests trumped religious prejudice.
\end{abstract}

We do not think it right that any Christian who wants to can kill a well-behaved Jew and go unpunished.

-Thomas of Monmouth, ca. $1150^{1}$
4 n Gentile Tales, Miri Rubin justly concluded that "most remaining traces" of medieval atrocities against Jews "represent the position of Christian authoritieschroniclers, preachers, town officials-who were almost always writing in defence or celebration of the events." 2 The exceptions to this rule, however, are illuminating. Some representations of attacks on Jews were produced for Jews, and it is not surprising that these construct the events quite differently. In this essay, though, I focus on another exceptional group of representations: images produced for Christians that condemn Christian acts of violence against Jews. These are admittedly few in number, yet their existence complicates our understanding of medieval anti-Semitism. The first part of this article explores an episode in a fourteenth-century French chronicle, the pillage of the Jews of Paris in 1380. The second part examines the tale of the murdered Jew, which first appears in late twelfth-century fable books. Both narratives-one drawn from a historical event, the other grafted onto an ancient fable-portray the Jew as the innocent victim and the Christian as the treacherous assailant. In this way, they reverse the better-known paradigm of the Jew as the evil aggressor who attacks innocent Christian boys or the consecrated host. This essay considers the circumstances that enabled some Christians to view with sympathy the figure of a vulnerable, attacked Jew. By examining in turn manuscripts

I would like to thank Zsofia Buda, Adam S. Cohen, Eva Frojmovic, Linda Safran, Fronia W. Simpson, Juliann Vitullo, and the anonymous readers for their thoughtful comments on a preliminary draft of this essay; Marie-Claire Waille for her generous help concerning the manuscript in Besançon; Andrew Taylor for help with the images; and the Oxford Centre for Hebrew and Jewish Studies, formerly at Yarnton Manor, for granting me the time and resources to complete this article. An earlier version of this paper was presented at the conference "Crossing Borders: Visualizing Jewish/Christian and Jewish/Muslim Relations in Medieval and Early Modern Times," which was held at Rice University in 2010. All translations are my own, unless otherwise indicated.

1. For the Latin original and an English translation, see Thomas of Monmouth, The Life and Miracles of St. William of Norwich, ed. and trans. Augustus Jessopp and Montague Rhodes James (Cambridge: Cambridge University Press, 1896), 102: "Licere autem cuilibet christiano quempiam pro libito suo bene merentem iudeum ita impune occidere nequaquam credimus; et quod non licere procul dubio constat si sic impunitum relinquatur, emulos multos eiusdem audatie futuros satisque deterius postmodum prouenire non dubitamus." For this quote, see Thomas of Monmouth, The Life and Passion of William of Norwich, trans. Miri Rubin (London: Penguin Books, 2014), 67. See below for a discussion of this passage.

2. Miri Rubin, Gentile Tales: The Narrative Assault on Late Medieval Jews (New Haven: Yale University Press, 1999), 3.

Gesta v55n1 (Spring 2016).

0031-8248/2016/7703-0004 \$10.00. Copyright 2016 by the International Center of Medieval Art. All rights reserved. 


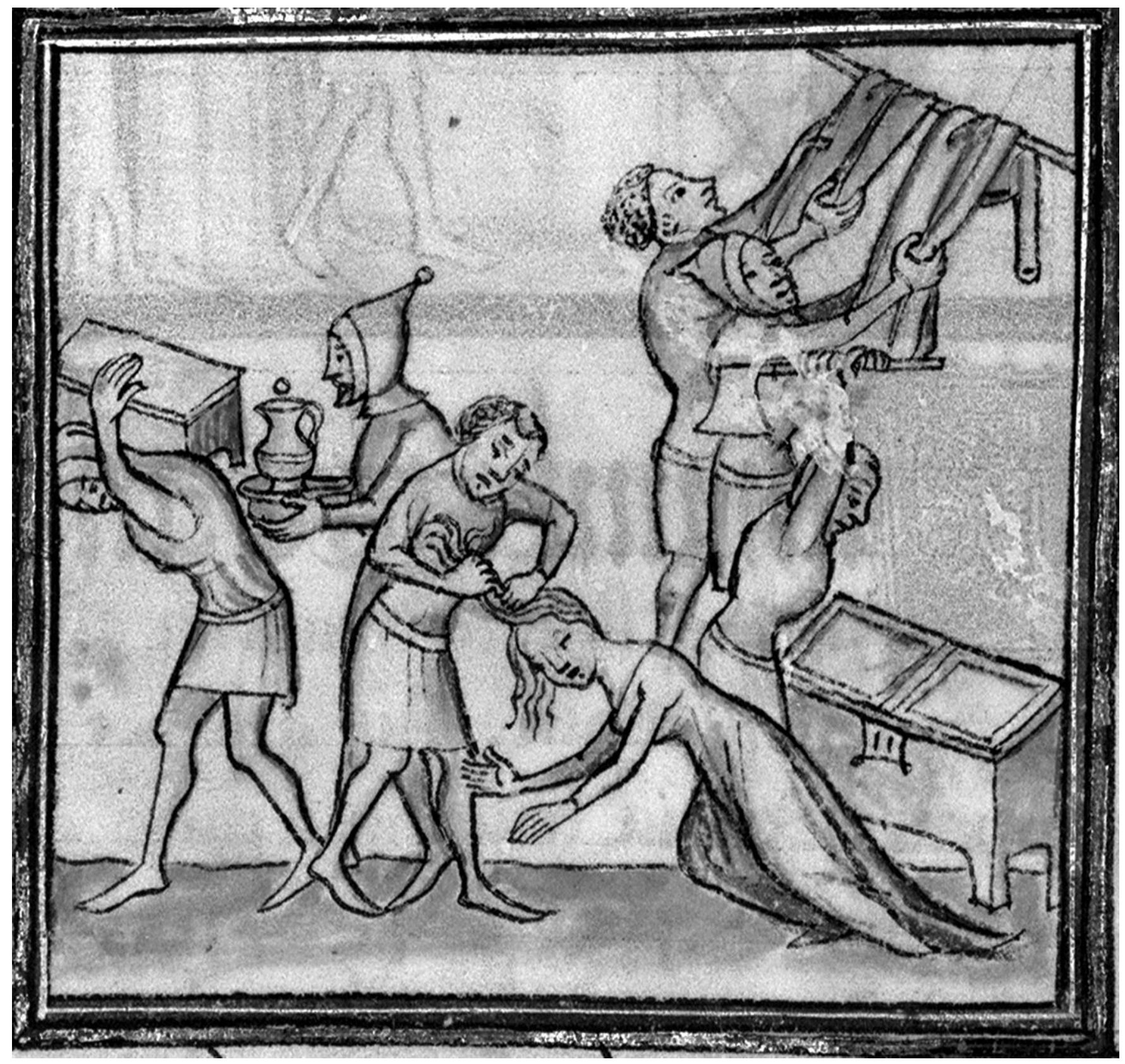

Figure 1. Pillage of a Jewish home, fol. 111r, Les fleurs des chroniques by Bernard Gui, 1384, Besançon, Bibliothèque municipale de Besançon, MS 677 (photo: CNRS-IRHT @ Bibliothèque municipale de Besançon). See the electronic edition of Gesta for a color version of this image.

made for the royal circle, aristocrats, and merchants, my study suggests that sometimes class interests trumped religious prejudice.

Les fleurs des chroniques

A scene of the pillage of a Jewish home appears in a version of Les fleurs des chroniques, a chronicle that traces the history of the world from its creation until 1383, the manuscript's terminus post quem (Fig. 1). ${ }^{3}$ Although neither its

3. For this manuscript, see Christiane Raynaud, La violence au Moyen Âge, XIIIe-XVe siècle: d'après les livres d'histoire en français (Paris: Léopard d'Or, 1990). For this illumination, see François Garnier, La guerre au Moyen Âge: XIe-XVe siècle; l'histoire par les documents iconographiques (Poitiers: INRDP, CRDP Poitiers, 1976), 46

$106:$ Gesta $\quad$ v55n1, Spring 2016 
provenance nor the identity of its patron is known, the manuscript consistently betrays the perspective of the French monarchy. Since Les fleurs des chroniques was originally written in 1368 for King Charles V of France, it is not surprising that the updated version continues to focus on royal events and to express the viewpoint of the French king. The chronicle was commissioned together with Bernard Gui's Arbor genealogiae regum Francorum, which sought to strengthen royal legitimacy and therefore is also consonant with the interests of the king. ${ }^{4}$ In general, the text of Les fleurs des chroniques is brief; it merely enables a reader to identify the particular action shown. The artist similarly summarizes and simplifies each event, relying heavily on symbolic visual language. ${ }^{5}$

In the illumination, Christian men pillage the home of a Jewish woman. No visual signs mark the woman or her home as Jewish, but the accompanying marginal note makes the subject clear. It reads, "The Jews of Paris who were pillaged" (Des Juifs de Paris qui furent robé). ${ }^{6}$ The miniature shows, in the right background, two men seizing costly garments from a rod, while below them another prepares to break open a large coffer with an ax. ${ }^{7}$ At the left, one thief removes expensive vessels and another carries away a small coffer on his shoulders, bending low under its weight. The visual focus, however, is at the center foreground, where a woman falls to her knees in an unstable pose, her arms helplessly outstretched before her as a man grasps her hair with both his hands. This is not a scene of a man pulling a woman's hair. Rather, in medieval art disheveled hair was often a sign of sexual

(who mistakenly identifies the setting as Ghent and reproduces the miniature in reverse); idem, Lâne à la lyre: sottiser d'iconographie médiévale (Paris: Léopard d'Or, 1988), 151; Raynaud, La violence au Moyen Âge, 170-71, 229, 335 (where the text is incorrectly transcribed; see note 13 below); and Diane Wolfthal, Images of Rape: The "Heroic" Tradition and Its Alternatives (Cambridge: Cambridge University Press, 1999), 69-72. Les fleurs des chroniques derives from Bernard Gui's Flores chronicorum, which was first composed in 1316 but repeatedly revised until the author's death in 1331. For Gui, see Antoine Leroux de Lincy, "Hugues Aubriot, prévot de Paris sous Charles V, 1367-1381," Bibliothèque de l'École des chartes 23 (1862): 173-213; Antoine Thomas, "Bernard Gui, frère prêcheur," Histoire littéraire de la France 35 (1921): 139-232, at 177-80; and Régis Rech, "Bernard Gui," in The Encyclopedia of the Medieval Chronicle, ed. Graeme Dunphy (Leiden: Brill, 2010), 1:170-72.

4. Perhaps Gui's Arbor genealogiae regum Francorum was paired with Les fleurs des chroniques because the latter was based on his Flores chronicorum.

5. François Garnier, Le langage de l'image au Moyen Âge: signification et symbolique (Paris: Léopard d'Or, 1982), 1: notes to figs. 16770 .

6. Fig. 4 shows this marginal inscription.

7. For a discussion of coffers and clothes hanging on bars as signs of wealth, see Garnier, La guerre au Moyen Âge, 46.

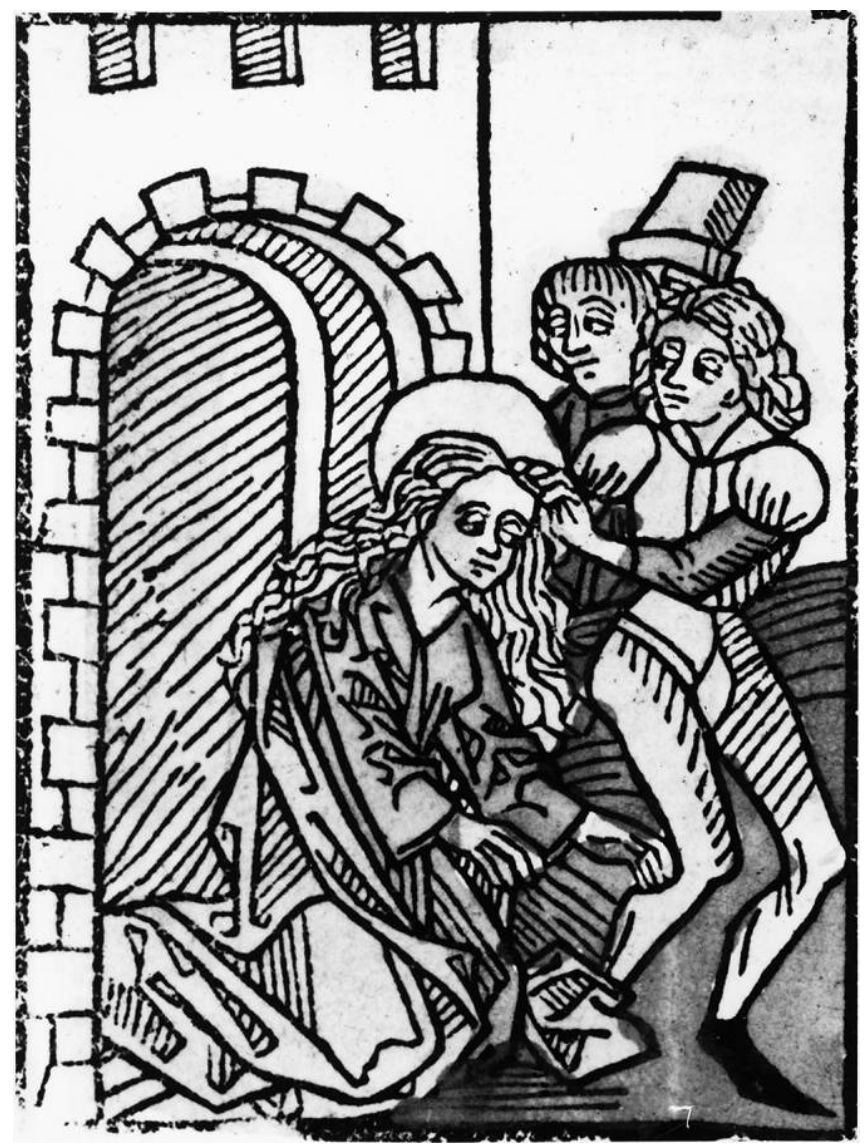

Figure 2. St. Agnes, Leben der Heiligen by Jacobus de Voragine, woodcut, Augsburg, 1485 (photo: Rare Books Collection, O. Meredith Wilson Library, University of Minnesota).

assault. Proper women throughout Europe covered their hair, and images of St. Agnes and the Levite's wife (Judg. 19), among others, show would-be rapists fondling their victims' long, loose hair. ${ }^{8}$ Furthermore, other fourteenth- and fifteenth-century illuminations-those showing the ancient Roman rapes of Boreas and Oreithia, Paris and Helen, and the Sabine women-portray victims of sexual violence with the same gesture as the woman in our chronicle, vulnerable, their arms extended before them. ${ }^{9}$ Perhaps the closest analogy is a woodcut of St. Agnes being threatened with rape in an edition of Jacobus de Voragine's Leben der Heiligen, which was published in Augsburg in 1485 (Fig. 2). In both images, a woman on or falling to her knees stretches out her arms as a man touches her loose, disheveled hair. As Heath Dillard has observed, "to be cast to the ground was damaging to a woman's dignity but often most demeaning when engineered

8. Wolfthal, Images of Rape, 39, fig. 17; 40, fig. 18; 44, fig. 23.

9. Ibid., 11, fig. 3 ; 131, figs. 77-78; 37, fig. 13. 


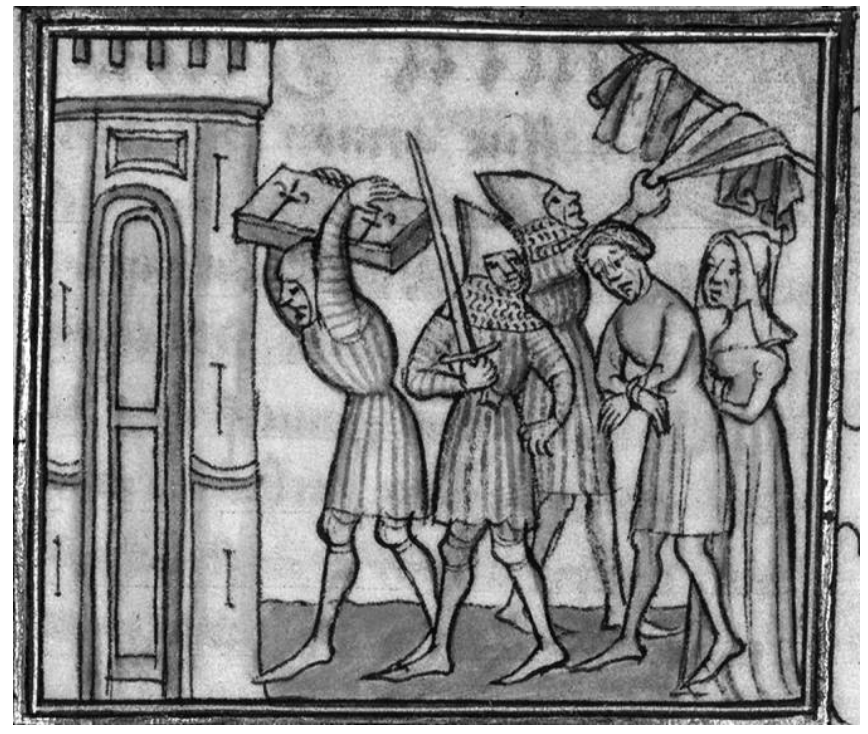

Figure 3. Soldiers from Ghent pillaging Bruges in 1382, fol. 115r, Les fleurs des chroniques by Bernard Gui, 1384, Besançon, Bibliothèque municipale de Besançon, MS 677 (photo: CNRS-IRHT (C) Bibliothèque municipale de Besançon). See the electronic edition of Gesta for a color version of this image.

by a man.... When a man removed a woman's coif or let down her hair, he assaulted her modesty and exposed her as defenseless and pregnable." ${ }^{10}$ In short, like the heroines of classical antiquity, the Levite's wife, and St. Agnes, the Jewish woman in the chronicle is portrayed as an innocent victim of sexual assault. ${ }^{11}$

Another miniature in Les fleurs des chroniques, which depicts soldiers from Ghent pillaging Bruges, offers additional support for the idea that the Jewess is an innocent victim (Fig. 3). Even though the illumination shows a man as well as a woman, and they are taken prisoner rather than assaulted, they suffer the same offenses committed against the Jewess of Paris: theft of a valuable coffer and expensive clothes. Through these visual similarities, the illuminator equates the aggrieved

10. Heath Dillard, Daughters of the Reconquest: Women in Castilian Town Society, 1100-1300 (Cambridge: Cambridge University Press, 1984), 175.

11. Although the miniature indicates that the woman was sexually assaulted, it does not make clear that she was raped because it lacks such undeniable visual signs of rape as the grasped wrist, torn clothes, or sexual intercourse, for which see Wolfthal, Images of Rape. This may well be due to the reticence that is a general characteristic of this manuscript, but Raynaud suggests that the illuminator avoids showing the most egregious offenses against the Jews, which would have been perceived as particularly outrageous violations of the doctrine of lèse-majesté. Raynaud, La violence au Moyen Âge, 26-27, 223-24, 229.

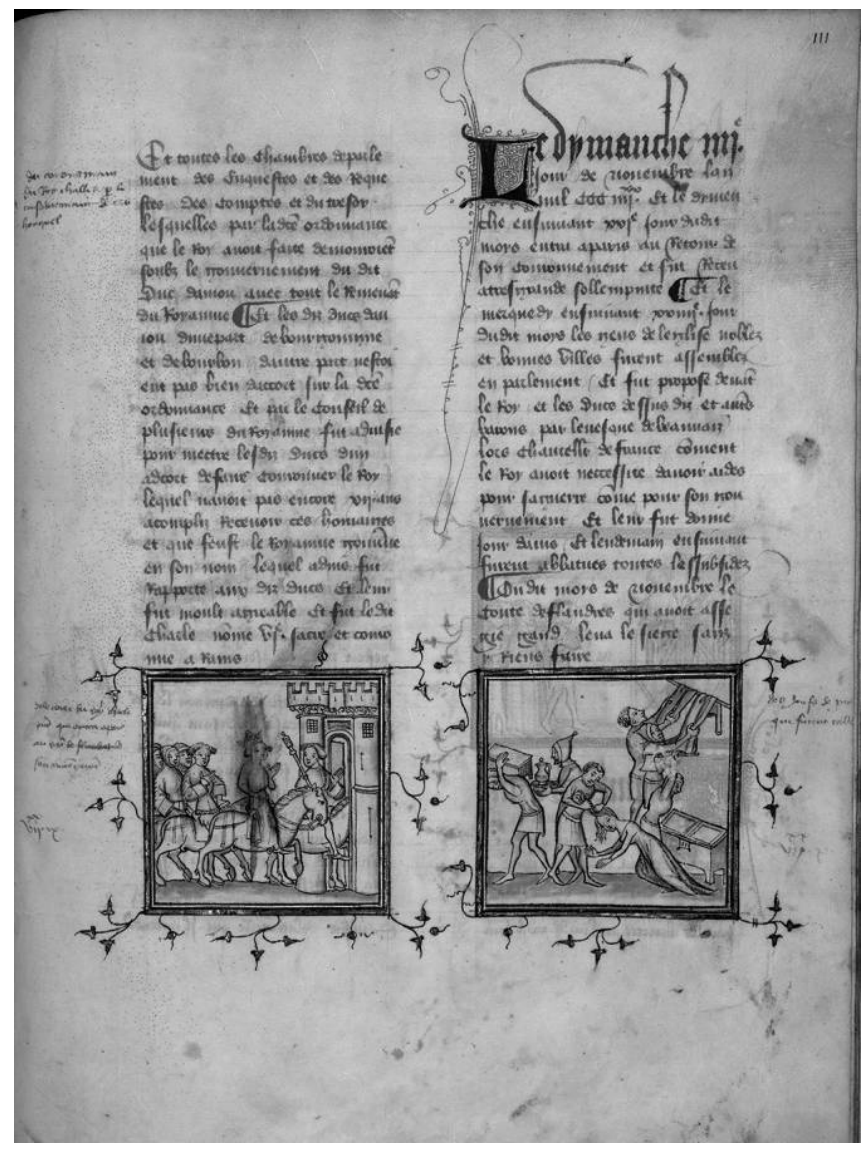

Figure 4. Les fleurs des chroniques by Bernard Gui, fol. 111r, 1384, Besançon, Bibliothèque municipale de Besançon, MS 677 (photo: CNRS-IRHT @ Bibliothèque municipale de Besançon).

parties and reinforces the idea that the Jewish woman, like the Christian couple in Bruges, is blameless and deserves our compassion. ${ }^{12}$

The text that accompanies the miniature of the pillage of a Jewish home elaborates the information supplied by the marginal note (Fig. 4). It reads, "On Thursday the fifteenth day of the said month of November 1380, several commoners and ordinary folk went to pillage the Jews of Paris; and several of them were put to death and their books torn." 13 The miniature, however, does not correspond to the text, since no Jews are shown slain or books destroyed. Why, then, did the artist represent robbery and sexual assault instead?

12. Raynaud, La violence au Moyen Âge, 229.

13. "Le jeudy XVe jour dudit moys de novembre l'an mil CCC IIII $^{x x}$ plusieurs poppullaires et gens de commun alerent rober les juifs de paris et furent plusieurs d'eulx mis à mort et leurs livres rompus." I thank Marie-Claire Waille for correctly transcribing this inscription.

$108:$ Gesta $\quad$ v55n1, Spring 2016 


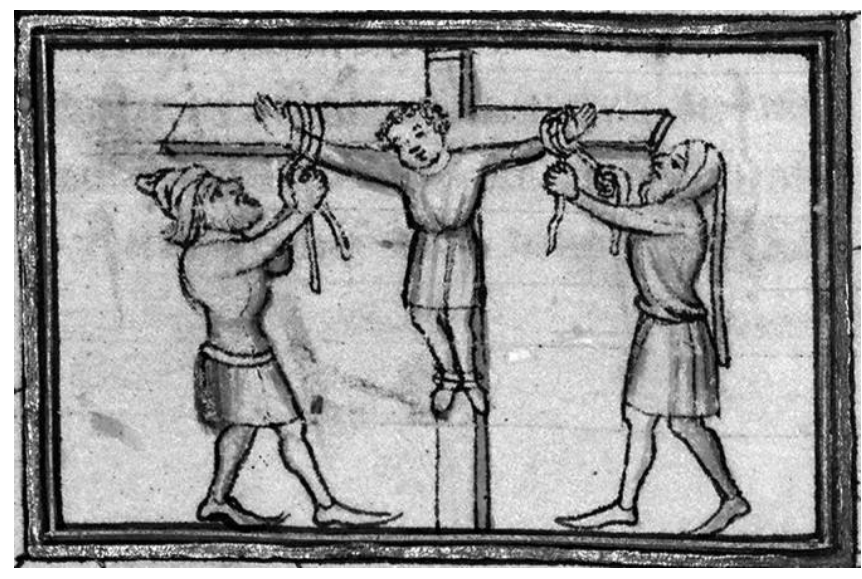

Figure 5. Crucifixion of William of Norwich, fol. 68r, Les fleurs des chroniques by Bernard Gui, 1384, Besançon, Bibliothèque municipale de Besançon, MS 677 (photo: CNRS-IRHT @ Bibliothèque municipale de Besançon). See the electronic edition of Gesta for a color version of this image.

To answer this question, we must first examine the only other image in this manuscript to show Jews, a representation of the alleged crucifixion of a young boy, William of Norwich, by Jews in 1144 (Fig. 5). This anti-Semitic theme, which was so often invoked to justify violence against Jews, portrays two Jewish men in a stereotyped, caricatured manner, as Christiane Raynaud has observed. ${ }^{14}$ The one on the left wears a turbanlike hat to suggest his foreignness, both men have noses that are larger than those of Christians in the manuscript, and both are bearded, unlike the Christians who are generally shown clean-shaven.

Recent publications by Sara Lipton help explain the gendered attitude toward Jews expressed in these illuminations. She convincingly argues that Christians caricatured male Jews in order to condemn Judaism's alleged "rigid obsolescence, its blind literalism, [and] the severity and intractability of its law." ${ }^{15}$ Lipton further observes that medieval stereotypes about women led Christian artists to conclude that Jewish women were ill suited to express these negative stereotypes. Instead, Jewish women were invoked to justify the protection of Jews within Christendom and to suggest the hope that they could be converted. Lipton concludes that these "notions [were] effectively embodied in the sign of the woman, whose face and body encode receptivity to dominance and potential

14. Raynaud, La violence au Moyen Âge, 326.

15. Sara Lipton, "Where Are the Gothic Jewish Women? On the Non-Iconography of the Jewess in the Cantigas de Santa Maria," Jewish History 22, nos. 1-2 (2008): 139-77, at 139; repr., eadem, Dark Mirror: The Medieval Origins of Anti-Jewish Iconography (New York: Metropolitan Books/Henry Holt, 2014), 220. for change." 16 The contrast between the Jewish men's cruel actions and stereotyped physiognomies and the Jewish woman's defenseless posture and normative facial features, which are indistinguishable from those of Christian women in the manuscript, would certainly have reflected and reinforced these gendered beliefs.

There is, however, a particular reason why this illuminator would have wanted to criticize violence against Jews. In expressing the viewpoint of the French monarchy, he sought to gain sympathy for the current royal policy of safeguarding the Jews. The pillaging depicted in Figure 1 took place on 15 November 1380, just two months after the death of Charles V. ${ }^{17}$ The new king, Charles VI, wished to continue his father's policy of protecting the small group of wealthy Jews because they were a critical source of revenue. ${ }^{18}$ Yet Parisian Jews were an easy target for an angry mob because they were a small community, who lived on a single street apart from Christians, and they were easily identifiable, since most were marked by a distinctive circular badge worn on their clothing. ${ }^{19}$ Jews were also an attractive target because they were not only wealthy but also had amassed their money by accepting such pawns as clothes, jewels, and reliquaries, and by lending at interest, a practice deemed sinful by Christian theologians. ${ }^{20}$ Chronicles relate that many of the Parisian rioters took their own pawns, either to free themselves of their debt

16. Lipton, "Where Are the Gothic Jewish Women?," 139; and eadem, Dark Mirror, 221.

17. The king died on 16 September. For the riot that followed, see Léon Mirot, Les insurrections urbaines au début du règne de Charles VI, 1380-1383: leurs causes, leurs conséquences (Paris: Fontemoing, 1905), 34-36, and sources in note 18 below.

18. Roger S. Kohn, "Les Juifs en France du Nord dans la seconde moitié du XIVe siècle: un état de la question," in L'expulsion des Juifs de France, 1394, ed. Gilbert Dahan with Elie Nicolas (Paris: Cerf, 2004), 13-29, at 21; and William Chester Jordan, The French Monarchy and the Jews: From Philip Augustus to the Last Capetians (Philadelphia: University of Pennsylvania Press, 1989), 248-50.

19. According to the chronicle of Michel Pintoin, in 1380 the Jewish community comprised forty houses. Chronique du religieux de Saint-Denys: contenant le règne de Charles VI, de 1380 à 1422, trans. M. L. Bellaguet (Paris: Crapelet, 1839), 54. For Jews living on one street and wearing the yellow badge, see Kohn, "Les Juifs en France du Nord," 24. Some Jews were exempted from wearing the badge; idem, "Les Juifs de la France du Nord à travers les Archives du Parlement de Paris (1359?-1394)," Revue des études juives 141, nos. 1-2 (1982): 5-138, at 51.

20. Because Jewish moneylenders generally dealt with people of modest means, few pawns were luxury items. Joseph Shatzmiller, Cultural Exchange: Jews, Christians, and Art in the Medieval Marketplace (Princeton: Princeton University Press, 2013), 9, 17. According to letters of remission, however (Mirot, Les insurrections urbaines, 35), rioters stole jewelry and a reliquary in the form of a sepulcher from Parisian Jews. 
or to prevent others from stealing them. The rioters also took to the street to protest high taxes. Although Charles V on his deathbed had revoked a household tax, the fouage, taxes on the consumption of goods, called aides, were still in place. ${ }^{21}$ In short, Jews were attacked in part because debtors resented their creditors, in part because of the rioters' anger at the taxes levied by the new king who protected the Jews, and in part because of the opportunity offered by the climate of unrest that followed the death of the previous king. ${ }^{22}$

Charles VI, during whose reign this manuscript of Les fleurs des chroniques was produced, would have viewed the attack on the Jews of Paris just two months into his administration as a particularly outrageous example of the crime of lèse-majesté, that is, an offense against his authority, since Jews were still under royal protection in the 1380s. By focusing on the sexual assault of an innocent woman who is indistinguishable from Christians in the manuscript; by showing the theft of clothes and coffers, the same acts committed against Christian victims in the manuscript; and by omitting any scenes that might explain the underlying causes for the riot, such as exorbitant taxes, the illuminator constructs the pillagers in an unambiguously negative light. If the illuminator had instead showed the destruction of Jewish books, an act mentioned in the accompanying text, this might have aroused negative feelings toward Jews. Such books might have been copies of the Talmud, which Christians believed contained "blasphemies and slurs" against Christianity and "made Jews obstinate in their perfidy," to quote a letter circulated by Pope Gregory IX in $1239 .{ }^{23}$ If they were account books, as the archives suggest, this might have reinforced the negative association between Jews and usury, something a king who wished to protect the Jews would also want to avoid. ${ }^{24}$

The miniatures that precede and follow the scene of the pillage of a Jewish home reinforce the message that the riot was a crime of lèse-majesté. The illumination that appears immediately to the left of the pillage scene helps establish

21. For the taxes levied by the kings and the opposition to them, see John Bell Henneman Jr., "France in the Middle Ages," in The Rise of the Fiscal State in Europe, ca. 1200-1815, ed. Richard Bonney (Oxford: Oxford University Press, 1999), 101-22, at 113-17.

22. Roger Kohn, "Les insurrections urbaines au début du règne de Charles VI et les Juifs," Revue des études juives 136, nos. 34 (1977): 517-23, at 520,522. For similar motives in an earlier attack, see David Nirenberg, Communities of Violence: Persecution of Minorities in the Middle Ages (Princeton: Princeton University Press, 1996), 48-50.

23. For the first quote, see Jordan, French Monarchy and the Jews, 137; for the second, see Hyam Maccoby, ed., Judaism on Trial: JewishChristian Disputations in the Middle Ages (London: Associated University Presses, 1982), 22.

24. Mirot, Les insurrections urbaines, 36.

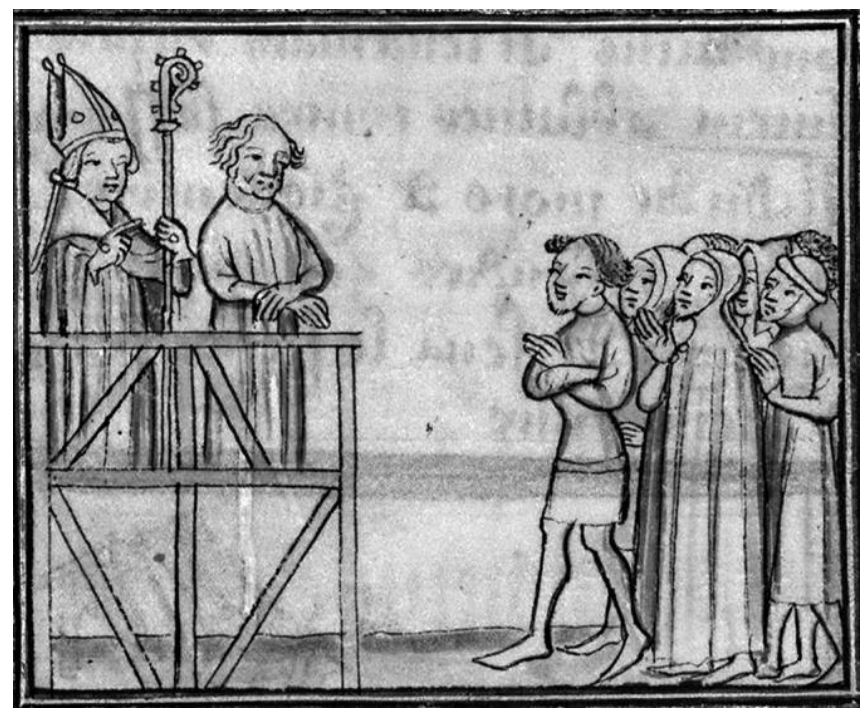

Figure 6. Hugues Aubriot doing public penance, fol. 111v, Les fleurs des chroniques by Bernard Gui, 1384, Besançon, Bibliothèque municipale de Besançon, MS 677 (photo: CNRS-IRHT @ Bibliothèque municipale de Besançon). See the electronic edition of Gesta for a color version of this image.

this framework by showing the entry of Charles VI into Paris after his coronation at Reims on 4 November 1380 (Fig. 4). The miniature that follows the attack on the Jewish home, on the reverse of the folio, depicts a scene of lèse-majesté, the church punishing Hugues Aubriot for an act that supported the king's policies (Fig. 6). Here Aubriot, the provost of Paris, is portrayed doing public penance for the crime of heresy, an event that took place in May $1381 .{ }^{25}$ An able administrator who improved the fortifications and sewers of Paris, Aubriot had earlier offended the Church and the university by pressuring them to support the schismatic pope in Avignon. The spark for the trumped-up charges of 1381, though, was his arrest of those who had assaulted the Jews four months earlier and his return to their Jewish families and their Jewish faith those children who had been forcibly seized and baptized. For that reason, Church authorities charged Aubriot

25. For the accusation and sentencing, see H. Omont, "Sentence de léveque de Paris condamnant Hugues Aubriot à une prison perpétuelle (1381)," Bulletin de la Société de l'histoire de Paris et de l'îlede-France 9 (1882): 156-58. For the charges, see Alexander Murray, "Beware of Universities: A Cautionary Tale from Paris, 1380-1381," in Medieval Paradigms: Essays in Honor of Jeremy duQuesnay Adams, ed. Stephanie Hayes-Healy (New York: Palgrave Macmillan, 2005), 2:29-54, at 45-47. For Aubriot's trial, see also Leroux de Lincy, "Hugues Aubriot," 198-200; and Eugène Déprez, Hugo Aubriot praepositus parisiensis et urbanus praetor (1367-1381) ... (Paris: Fontemoing, 1902).

$110 \therefore \quad$ Gesta $\quad$ v55n1, Spring 2016 


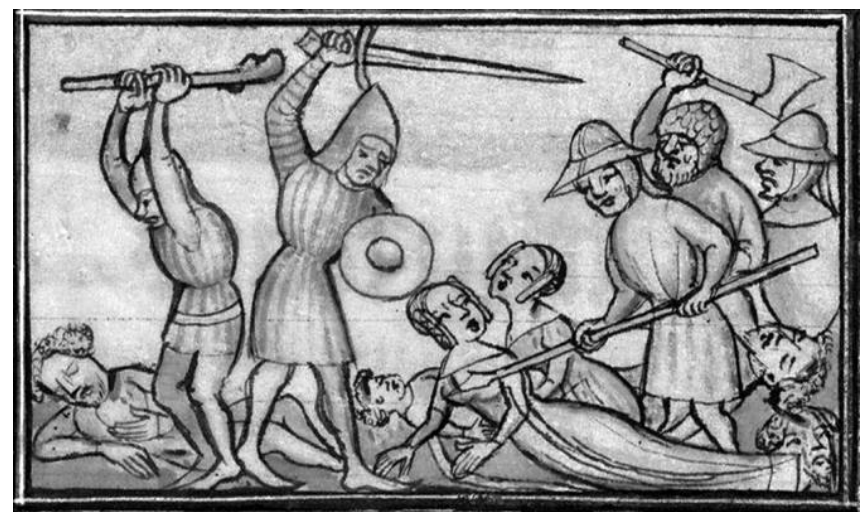

Figure 7. Revolt of the Jacquerie in 1358, fol. 98r, Les fleurs des chroniques by Bernard Gui, 1384, Besançon, Bibliothèque municipale de Besançon, MS 677 (photo: CNRS-IRHT @ Bibliothèque municipale de Besançon). See the electronic edition of Gesta for a color version of this image.

with "abetting the Jewish perfidy." ${ }^{\text {26 }}$ Unlike other accounts of his public penance, here Aubriot stands, rather than kneels, and in this way is granted greater dignity, which conforms to the manuscript's restrained style and its consistent support for the king's policies. ${ }^{27}$ This miniature reinforces the view that the preceding scene, the pillage of a Jewish home, should also be interpreted as an unjust act, an offense against royal authority.

A key element for interpreting the scene of pillage is that both its text and its image clearly mark the assailants as commoners. The text calls them "commoners and ordinary folk," and the miniature portrays them as such by their simple, short garments. ${ }^{28}$ Yet other contemporary chronicles assert that noblemen not only participated in the riots but also incited them. ${ }^{29}$ The erasure of the noblemen's complicity in Les fleurs des chroniques therefore demands an explanation.

This manuscript is not the only source to link commoners with sexual assault and brutality. The chronicler Jean Froissart noted that the Jacquerie, members of a popular revolt in 1358, raped women, and concluded, "Never did men commit such vile deeds.... I could never bring myself to write down the

26. Due to the intervention of the duke of Burgundy, Aubriot's sentence was commuted to life in prison with only bread and water. When a mob later released him, Aubriot fled the city. Jean Guiraud, The Medieval Inquisition, trans. E. C. Messenger (Kila, MT: Kessenger, 2003), 201-2.

27. For the kneeling posture of Aubriot, see Leroux de Lincy, "Hugues Aubriot," 197-200.

28. The text reads "poppullaires et gens de commun." For short clothes as denoting the working class, see Margaret Scott, Fashion in the Middle Ages (Los Angeles: J. Paul Getty Museum, 2011), 78.

29. Kohn, "Les insurrections urbaines," 519; and idem, "Les Juifs de la France du Nord," 52. horrible and shameful things which they did to the ladies." ${ }^{30}$ The miniature in Les fleurs des chroniques, painted in the restrained style typical of this manuscript, reinforces such views by representing the riot of 1380 with an image of a woman being sexually assaulted by a commoner. This is part and parcel of the way the manuscript constructs this class of Frenchmen, who are sometimes shown as obedient workers but elsewhere as despicable rioters, as in the revolt of 1358, which is rendered by a scene of peasants slaughtering innocent aristocratic men, women, and children (Fig. 7). ${ }^{31}$ From the illuminator's point of view the key figure in the episode of 1380 , although unseen, is the king. The miniature's true subject is the conflict between royal authority and the uncontrollable mob. The Jews are powerless pawns in this struggle. Yet the scene of pillage may well have sparked, in the minds of some readers, a modicum of sympathy for the Jewish victim whom it portrayed (Fig. 1).

For the Jewish community of Paris, the riot of 1380 had quite a different meaning. Jews had only been readmitted to the kingdom of France some twenty years earlier and, according to Roger Kohn, the single day of pillage and another threeday massacre two years later resulted in the economic ruin of the Jewish community. He argues that this ultimately led to their expulsion in 1394, when they were no longer a fruitful source of income for the king. ${ }^{32}$ Jews and Christians interpreted violence against Jews in radically different ways. To my knowledge, no scene of the pillage of a Jewish home appears in any Jewish manuscript. ${ }^{33}$ Similarly, I know of no medieval Jewish representations of contemporary atrocities; instead, these are visually commemorated through renderings of

30. For the English translation, see Jean Froissart, Chronicles, trans. and ed. Geoffrey Brereton (Harmondsworth: Penguin Books, 1968), 151-52. For the original French, see Les chroniques de sire Jean Froissart, ed. J. A. C. Buchon (Paris: Wattelier, 1867), 1:375-76: "Certes oncques n'avint entre Chrétiens et Sarrasins telle forcenerie que ces gens faisoient, ni que plus fissent de maux et de plus vilains faits. . . Je n'oserois écrire ni raconter les horribles faits et inconvenables que ils faisoient aux dames."

31. As Raynaud (La violence au Moyen Âge, 331) convincingly argues, even though the peasants are armed, they would not be mistaken for soldiers.

32. Kohn, "Les insurrections urbaines," 518; and idem, "Les Juifs en France du Nord," 21, 24.

33. Thérèse Metzger and Mendel Metzger, Jewish Life in the Middle Ages: Illuminated Hebrew Manuscripts of the Thirteenth to the Sixteenth Centuries (Secaucus, NJ: Chartwell Books, 1982), 196, wrongly identify their fig. 278 as a scene of pillage. It illustrates instead a fable in Isaac ben Solomon ibn Sahula's Meshal ha-Kadmoni (The Fable of the Ancient), in which an adulterous wife runs off with her husband's riches. Isaac ibn Sahula, Meshal Haqadmoni: Fables from the Distant Past; A Parallel Hebrew-English Text, ed. and trans. Raphael Loewe (Oxford: Littman Library of Jewish Civilization, 2004), 1:188-95.

Complicating Medieval Anti-Semitism $\sim$ : 111 


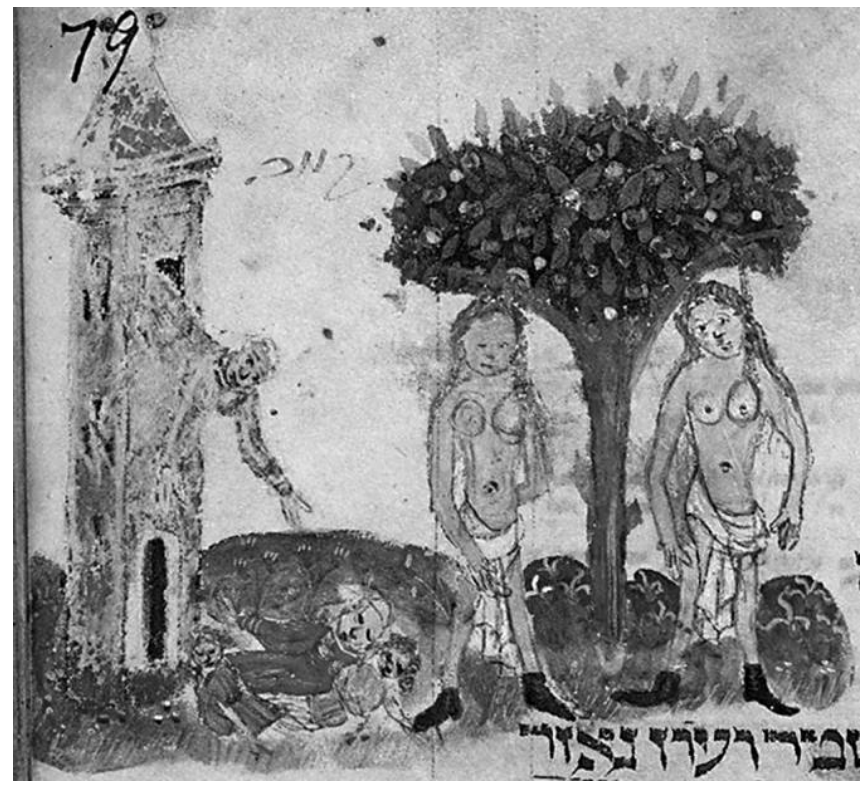

Figure 8. Punishments for circumcising babies, fol. 79v, Hamburg Miscellany, 1420s-30s, Hamburg, Staats- und Universitätsbibliothek, cod. Heb. 37 (photo: Hamburg, Staats- und Universitätsbibliothek, Handschriftenabteilung). See the electronic edition of Gesta for a color version of this image.

ritual observances, such as Purim or Tisha b'Av, or incidents that occurred in the distant past. ${ }^{34}$ For example, the Hamburg Miscellany, a manuscript created in the area of Mainz in the 1420 s and 1430s, shows Jews imprisoned, stabbed, beaten with switches, mutilated, tortured, decapitated, murdered, and forced to leave town..$^{35}$ These illuminations-which show the Maccabean martyrs of the second century BCE-would have been interpreted by their Jewish audience as scenes of sacrifice that could lead to redemption and as commemorations of more recent events, such as the persecutions that occurred during the crusades. ${ }^{36}$ One scene might suggest sexual

34. Purim commemorates the defeat of Haman, who plotted to massacre the Jews of Persia. Tisha b'Av commemorates the destruction of the First and Second Temples in Jerusalem as well as later catastrophes that befell the Jews on the ninth of the month of Av.

35. Metzger and Metzger, Jewish Life in the Middle Ages, 191-92, figs. 267, 269-74.

36. For the Hamburg Miscellany, see Zsofia Buda, "Sacrifice and Redemption in the Hamburg Miscellany: The Illustrations of a Fifteenth-Century Ashkenazi Manuscript" (PhD diss., Central European University, 2013), esp. 182-85 for the illumination of the women hung by their breasts. I thank Dr. Buda for sharing her research with me. See also Sarit Shalev-Eyni, "Martyrdom and Sexuality: The Case of an Eleventh-Century Piyyut for Hanukkah and Its Visual Interpretation in the Fifteenth Century," in Conflict and Religious Conversation in Latin Christendom: Studies in Honour of Ora Limor, ed. Israel Yuval and Ram Ben-Shalom (Turnhout: Brepols, 2014), 133-65.

$112: \quad$ Gesta $\quad$ v55n1, Spring 2016 violence: two Jewish women, nude except for loincloths, hang by their breasts in a composition that recalls representations of the martyrdom of St. Agatha, whose breasts were cut off (Fig. 8). ${ }^{37}$ Unlike Christian images, this scene has nothing to do with preserving the virginity of the women. Instead, female Jewish martyrs were generally married or pregnant, and their breasts would have been associated by a Jewish audience primarily with their ability to nourish their children. Furthermore, unlike Christian scenes of martyrdom, this image does not include the torturers of the women. No man touches these Jewish women, unlike the scene in the French chronicle. That Christians sexually assaulted Jewish women may have been considered too shameful to depict.

Nonetheless, the scene of the pillage of a Jewish home is strikingly different from the vast majority of Christian images that show offenses against Jews (Fig. 1). The typical medieval Christian attitude is expressed in the inscription on an engraving of the Regensburg synagogue by Albrecht Altdorfer, which states that its destruction in 1519 was "according to God's just judgment." ${ }^{38}$ By contrast, the illumination in Les fleurs des chroniques is primarily concerned with the assertion of royal authority, and for this reason it unequivocally condemns the pillage of the Jewish community.

\section{The Fable of the Murdered Jew}

Although only one image of the riot of 1380 is known, more than thirty depict the fable of the murdered Jew. These date from the late thirteenth through the late seventeenth century and appear in manuscripts and printed books written in French, German, Italian, Latin, and Yiddish. Because of their broad geographic and temporal range, and because printed books are reproduced in multiple copies, the audience for this fable must have been much larger and more diverse than that for Les fleurs des chroniques. For this reason, images of the fable likely had a greater impact on how European Christians viewed Jews, and they also offer an opportunity to understand better how local history and local concerns affected representations of Jews.

Although chronicles like Les fleurs des chroniques are early forms of historical writing, fables are fiction. A popular literary genre in medieval Europe, these short narrative tales

37. I thank Zsofia Buda for calling this image to my attention.

38. The text reads, "iusto dei iudicio." J. M. Minty, "Judengasse to Christian Quarter: The Phenomenon of the Converted Synagogue in the Late Medieval and Early Modern Holy Roman Empire," in Popular Religion in Germany and Central Europe, 1400-1800, ed. Bob Scribner and Trevor Johnson (Basingstoke: Macmillan, 1996), 78. For this print, see also Kathleen Biddick, "Paper Jews: Inscription/Ethnicity/Ethnography," Art Bulletin 78, no. 4 (1996): 594-99. 
served as both entertainment and exempla. ${ }^{39}$ Although medieval writers attributed their fables to the legendary Greek storyteller Aesop, their earliest versions stem from such Latin fabulists as the first-century Phaedrus and the fifth-century Flavius Avianus. ${ }^{40}$ The first medieval collections of fables were written in Latin to teach ethics and grammar, but by the twelfth century vernacular editions began to appear. If initially the audience for fables was largely aristocratic, gradually it came to include merchants and humanists interested in ancient Graeco-Roman culture. In this section, I trace the changing meaning of the fable of the murdered Jew from its origins at the twelfth-century English royal court, to its subsequent interpretations for Franc-Comtois and Burgundian aristocrats, to its final medieval transformation in the mercantile centers of fifteenth-century Tuscany. Despite changes in the fable as it traveled in time and space, its text-and usually its imagery-made clear that an innocent Jew was killed by a greedy Christian.

\section{From the Murder of Ibycus to the Fable of Walter of England}

The fable of the murdered Jew may be traced back in its broad outlines to an ancient Greek tale about the poet Ibycus, who lived in the sixth century BCE. ${ }^{41}$ A robber critically wounded him, but before dying, the poet implored a flock of cranes that had witnessed the attack to avenge his death. They shadowed the murderer to a stadium, where they hovered overhead until he confessed his crime. He was then seized, tried, and sentenced to death. Among the many modifications of this fable that evolved during the Middle Ages was the transformation of Ibycus into a Jew.

39. The literature on medieval fables is vast. Recent publications include Francisco Rodríguez Adrados, History of the Graeco-Latin Fable, trans. Leslie A. Ray, 3 vols. (Leiden: Brill, 1999-2003); and Edward Wheatley, Mastering Aesop: Medieval Education, Chaucer, and His Followers (Gainesville: University Press of Florida, 2000). See also notes $40-43$ below.

40. For a recent overview of medieval fables, see Françoise FeryHue, "Isopets," in Dictionnaire des lettres françaises, ed. Geneviève Hasenohr and Michel Zink (Paris: Fayard, 1994), 1:716-18. For the medieval view of Aesop, see Keith Busby, Codex and Context: Reading Old French Verse Narrative in Manuscript (Amsterdam: Rodopi, 2002), 215

41. For this fable, see Plutarch, Plutarch's Moralia, trans. W. C. Helmbold (London: Heinemann, 1939), 6:438-39; Greek Lyric, ed. and trans. David A. Campbell (Cambridge, MA: Harvard University Press, 1991), 3:208-11; Antti Aarne and Stith Thompson, The Types of the Folktale: A Classification and Bibliography, 2nd rev. ed. (Helsinki: Academia Scientiarum Fennica, 1961), AaTh 960A, The Cranes of Ibycus; and Rodríguez Adrados, History of the GraecoLatin Fable, 3:668-69.
The first medieval version to incorporate this change is a collection of Latin fables composed about 1175 and generally attributed to Walter of England. ${ }^{42}$ This book was the most influential source for fables in the late Middle Ages. ${ }^{43}$ Although fifty-eight of its sixty fables derive from those by the legendary Romulus, which in turn stem from the collection of Phaedrus, the fable of the murdered Jew is one of two tales, both placed at the end of the book, whose derivation is unknown. ${ }^{44}$ In Walter's version, a Jew asks a king for safe conduct through a dangerous forest in exchange for gifts. The royal cupbearer agrees to protect the Jew, but instead robs and kills him. Before dying, the Jew predicts that a partridge that witnessed the crime will denounce the murderer. When the cupbearer later sees the bird being readied for the king's dinner, he laughs uncontrollably. The king demands an explanation for this outburst, whereupon the murderer confesses and is executed. Since the cupbearer was a trusted member of the king's inner circle, a servant of high rank whose duty it was to ensure that the monarch's wine was not poisoned, this initial version of the tale is primarily about obeying the royal order to protect a Jew. But it is also a tale of greed. As Esther Zago, Janice Owen, and Michael Serwatka justly conclude, "What we have here is a reversal of roles: it is the Jew who is victimized by the avarice of a Christian." ${ }^{45}$

Thomas Edward Wheatley concludes that the fable of the murdered Jew is "notable for its avoidance of anti-semitism," but Aaron E. Wright goes too far when he asserts that the Jew's religious identity is "purely incidental and neutrally

42. For the identity of Walter of England, the dating of his fables, and his version of the tale, see Esther Zago, Janice Owen, and Michael Serwatka, "The Jew and the King's Cup-Bearer: A Tale of Jewish Life in Medieval Europe," Fabula 42, nos. 3-4 (2000): 21342 , at $214-16,218$. The authors transcribe and translate the version appearing in Paris, Bibliothèque nationale de France (hereafter BnF), MS lat. 14381. For the general acceptance of Walter as the author of these fables, see Fery-Hue, "Isopets," 716. A few remain unconvinced of this identity, including Jeanne-Marie Boivin, Naissance de la fable en français: l'Isopet de Lyon et l'Isopet I-Avionnet (Paris: Champion, 2006), 132-33, who, however, did not know the article by Zago, Owen, and Serwatka. For this fable, see also Aaron E. Wright, The Fables of "Walter of England" (Toronto: Pontifical Institute of Mediaeval Studies, 1997), 151-55, no. 59; and Thomas Edward Wheatley, "The 'Fabulae' of Walter of England, the Medieval Scholastic Tradition, and the British Vernacular Fable" (PhD diss., University of Virginia, 1991), 47.

43. It is preserved in more than a hundred manuscripts as well as in printed books. Kenneth McKenzie and William A. Oldfather, Ysopet-Avionnet: The Latin and French Texts (Urbana: University of Illinois Press, 1919), 230.

44. Boivin, Naissance de la fable en français, 134.

45. Zago, Owen, and Serwatka, "Jew and the King's Cup-Bearer," 230.

Complicating Medieval Anti-Semitism $\sim 113$ 
described." ${ }^{46}$ Searching for a pretext for the robbery that precipitated the murder, Walter of England seized on the idea of a Jewish victim, in part because he associated Jews with wealth. As John D. Martin observes, medieval fables that involve human actors rely on stereotypes, whether the knight, the farmer, the housewife, or the Jew. ${ }^{47}$ This version twice states that the Jew was carrying "his wealth." ${ }^{48}$ In this way, the tale reinforces the negative association between Jews and money.

Zago, Owen, and Serwatka convincingly argue that the decision to transform Ibycus into a Jew was made in response to a historical event, the murder of a Jew named Eleazar in an English forest about $1146 .{ }^{49}$ Although he was one of the Jews who had been falsely accused of the ritual killing two years earlier of twelve-year-old William of Norwich, Eleazar was not executed for that crime. Instead, he was assassinated by the squires of one of his debtors, Simon de Novers, who lured him into the woods on the pretense of repaying the knight's debt and instead stabbed him to death. Our source for this incident is the second volume of Thomas of Monmouth's hagiography of William, which was written before 25 October 1154 . It became better known with the completion of Thomas's final volume in $1172 / 73$, shortly before the first appearance of the fable of the murdered Jew. ${ }^{50}$ Thomas's account of the murder of Eleazar shares many similarities with the later fable: the victim is a rich Jew, fatally stabbed with a sword in an isolated woods in a treacherous manner by a Christian whose goal was monetary gain. One key difference between the two tales is that in The Life of William of Norwich, and presumably in actuality, the murderers of Eleazar of Norwich were never punished, whereas in the fable, written from the viewpoint of the English king, the assailant who disobeys a royal order is executed. Zago, Owen, and Serwatka demonstrate that through this reworking of an ancient fable, Walter of England, the chaplain of King Henry II, intended to issue a warning against harming the Jews whom the king protected.

46. Wheatley, "'Fabulae' of Walter of England," 56; and A. E. Wright, "Hie lert uns der meister": Latin Commentary and the German Fable, 1350-1500 (Tempe: Arizona Center for Medieval and Renaissance Studies, 2001), 48.

47. John D. Martin, Representations of Jews in Late Medieval and Early Modern German Literature (Oxford: Peter Lang, 2004), 156.

48. Zago, Owen, and Serwatka, "Jew and the King's Cup-Bearer," 215-16 ("opes").

49. Ibid., 213-14, 221.

50. Gavin I. Langmuir, "Thomas of Monmouth: Detector of Ritual Murder," Speculum 59, no. 4 (1984): 820-46, at 838-39, 844. For the date of book 2, see John M. McCulloh, "Jewish Ritual Murder: William of Norwich, Thomas of Monmouth, and the Early Dissemination of the Myth," Speculum 72, no. 3 (1997): 698-740, at 706. For dates, see also Thomas of Monmouth, Life and Passion of William of Norwich, xviii, xix.

$114 \therefore$ Gesta $\quad$ v55n1, Spring 2016
Indeed, Henry's predecessor, King Stephen, was personally involved in this case. ${ }^{51}$ His sheriff had defended the Jews of Norwich against the bishop who wished to charge them with William's murder. The Jews found refuge in the royal castle when their lives were threatened, and the king issued an edict guaranteeing their safety. He also refused to respond to the bishop's charges against them. The king had initiated a policy of not only maintaining the Jewish presence in London but also expanding it to royal cities throughout England as a way to foster trade and fill the royal coffers. His successor continued this policy, and Henry's reign has been termed a "Golden Age for the Jews." ${ }^{2}$ Much like the image of the pillage of a Jewish home (Fig. 1), the fable of the murdered Jew was composed by someone in the circle of a king who wished to protect the Jews, and whose policy was opposed by the local clergy as well as by many commoners. Furthermore, like the riot in Paris, the murder of Eleazar and its aftermath were not simply about anti-Jewish prejudice. Christians were divided, and religious prejudice was intensified by class conflict, since animosity against Jews was tightly bound with native English hostility toward their new Norman overlords. ${ }^{53}$ Jews, who had entered England with the Normans and continued to speak French until their expulsion in 1290, were to a great extent viewed as foreigners. ${ }^{54}$ That the kings of England protected Jews only reinforced antipathy against them. In addition, antiJewish sentiment was compounded by the usual resentment of debtors toward their creditors. After Edward I expelled the Jews, even the English royalty lost interest in this tale, and the fable never again appeared in English versions.

\section{Illuminations from Franche-Comté and Burgundy}

Walter's original manuscript is lost, but it survives in subsequent versions. The core story remains the same: an innocent Jew is harmed by a Christian servant who has defied his lord and is executed as a result. The appeal of the tale continues to lie in its entertainment value and its meaningful moral about the evils of greed. After Walter's time, however, the fable took

51. Kevin T. Streit, "The Expansion of the English Jewish Community in the Reign of King Stephen," Albion: A Quarterlv Journal Concerned with British Studies 25, no. 2 (1993): 177-92; and Robert C. Stacey, "Jews and Christians in Twelfth-Century England: Some Dynamics of a Changing Relationship," in Jews and Christians in Twelfth-Century Europe, ed. Michael A. Signer and John Van Engen (Notre Dame, IN: University of Notre Dame Press, 2001), 340-54.

52. "The History of the Medieval Jews of England," http://www .oxfordjewishheritage.co.uk/english-jewish-heritage/68-english -jewish-heritage.

53. Streit, "Expansion of the English Jewish Community," 184.

54. Stacey, "Jews and Christians in Twelfth-Century England," 341. 


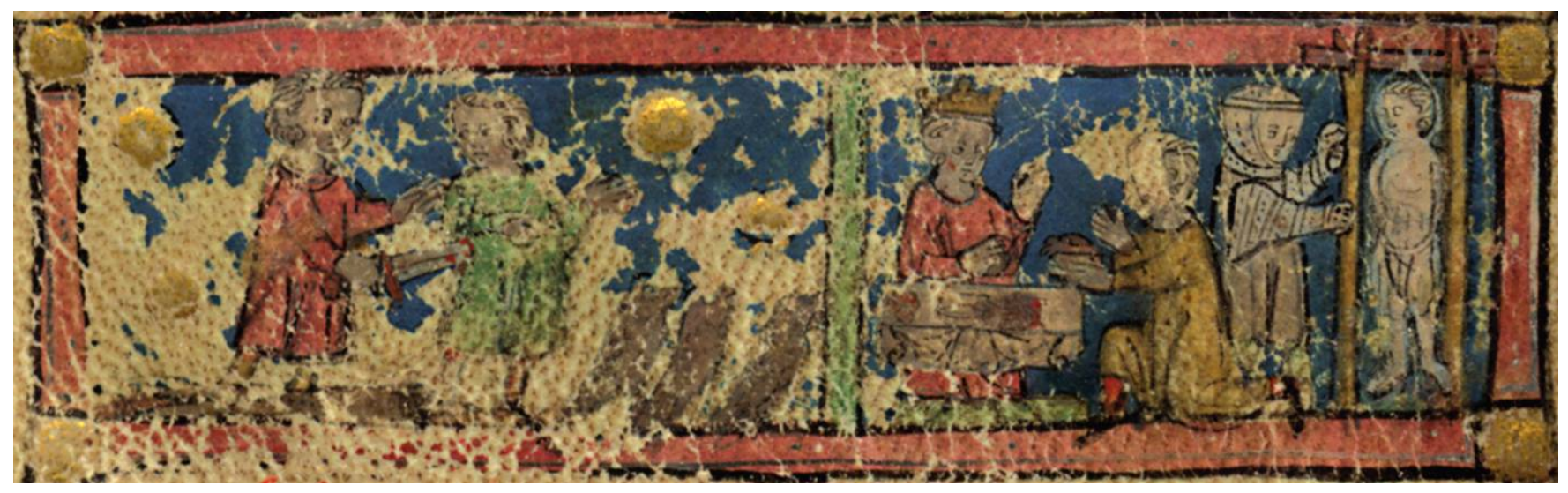

Figure 9. Fable of the murdered Jew, fol. 82v, Isopet de Lyon, made in Franche-Comté, thirteenth century, Lyons, Bibliothèque municipale, MS Palais des Arts 057 (photo: (C) Bibliothèque municipale de Lyon, Didier Nicole).

on a life of its own. No longer did it issue from the royal circle and have as a primary motivation the desire to express disapproval of underlings who disobey the king and harm his Jews. Since many collections of fables that are derived from Walter's omit the tale of the murdered Jew, the specific motivation for including it and the ways in which it would have been interpreted must be understood as rooted in local history.

The earliest extant images of the fable were produced in Franche-Comté and Burgundy in the late thirteenth and fourteenth centuries. The oldest surviving illustration appears in an Isopet de Lyon, which consists of sixty tales derived from those by Walter of England (Fig. 9). ${ }^{55}$ Each story is interpreted first by a Latin text, then by an illumination, and finally by a Franc-Comtois variant. This dialect and the provincial style of the illuminations help localize the manuscript's provenance. ${ }^{56}$ Unfortunately, the name of the person who ordered the collection has been effaced and is illegible even under ultraviolet light, but this sumptuously illuminated codex, written in Latin and the vernacular, could only have been produced for a wealthy and educated, presumably aristocratic, patron. ${ }^{57}$

55. For this manuscript, see Françoise Cotton, "Les manuscrits à peintures de la Bibliothèque de Lyon: essai de catalogue," Gazette des beaux-arts, ser. 6, 65 (May-June 1965): 165-320, at 276-77; Busby, Codex and Context, 216-19, 222; and Louis Holtz and Pierre Guinard, Manuscrits médiévaux: de l'usage au trésor; 21 septembre-4 janvier 2002 (Paris: Bibliothèque Municipale de Lyon la Part-Dieu, 2002), 62. For the text of Isopet de Lyon, see Julia Bastin, ed., Recueil général des Isopets (Paris: Société des Anciens Textes Français, 1929-), 2 (1930): 186-90. For its date (probably end of the thirteenth century, at the latest fourteenth century), see Wendelin Foerster, ed., Lyoner Yzopet: altfranzösische Übersetzung des XIII. Jahrhunderts in der Mundart des Franche-Comté (Heilbronn: Henninger, 1882), i.

56. For the provincial style, see Busby, Codex and Context, 216.

57. Ibid., 217, 219.
Each framed miniature spans the full width of the text, and most are divided into two compartments. The poorly preserved miniature shows, at the left, the servant plunging his sword into his victim, who gestures toward the missing area above the three brown tree trunks to his right. Presumably he is pointing to a partridge that is no longer visible. In the right half, the servant, now termed a butler (botoillier), kneels in obeisance while serving the bird to the king. To the right a sentinel guards the murderer, who is stripped to the waist and hangs from a gallows, his eyes closed to indicate that he is dead. This visualizes the lines of the poem that read, "Let him be hanged at the gallows / he who has shed the blood of the Jew." ${ }^{58}$

Unlike the assailants in the image of the Paris riot (Fig. 1), the offender here is not a commoner; generally butlers came from the elite class. For this reason he is shown wearing a long garment and is permitted to use a sword. Nonetheless, he is clearly subservient to the king, before whom he kneels. The butler's treachery is visualized through the posture of his victim, who turns his head around to look at his assassin, who must be stabbing him in the back. The depiction of the hanging makes clear the severe punishment that awaits disobedient servants who fail to safeguard the king's Jews. Like the scene of the pillage of a Jewish home, but in contrast to so many other contemporary images, the Franc-Comtois miniature does not differentiate the Jew from the other figures. His physiognomy and garments are indistinguishable from those of the butler, and he is not accompanied by any signs of wealth. Unlike the servant, the Jew is not criticized in any way.

58. Zago, Owen, and Serwatka, "Jew and the King's Cup-Bearer," 230, give the translation and its original language: "Que ciz soit a forches penduz, / Qui du Juif ai espandu / Lo sang."

Complicating Medieval Anti-Semitism $\sim 115$ 


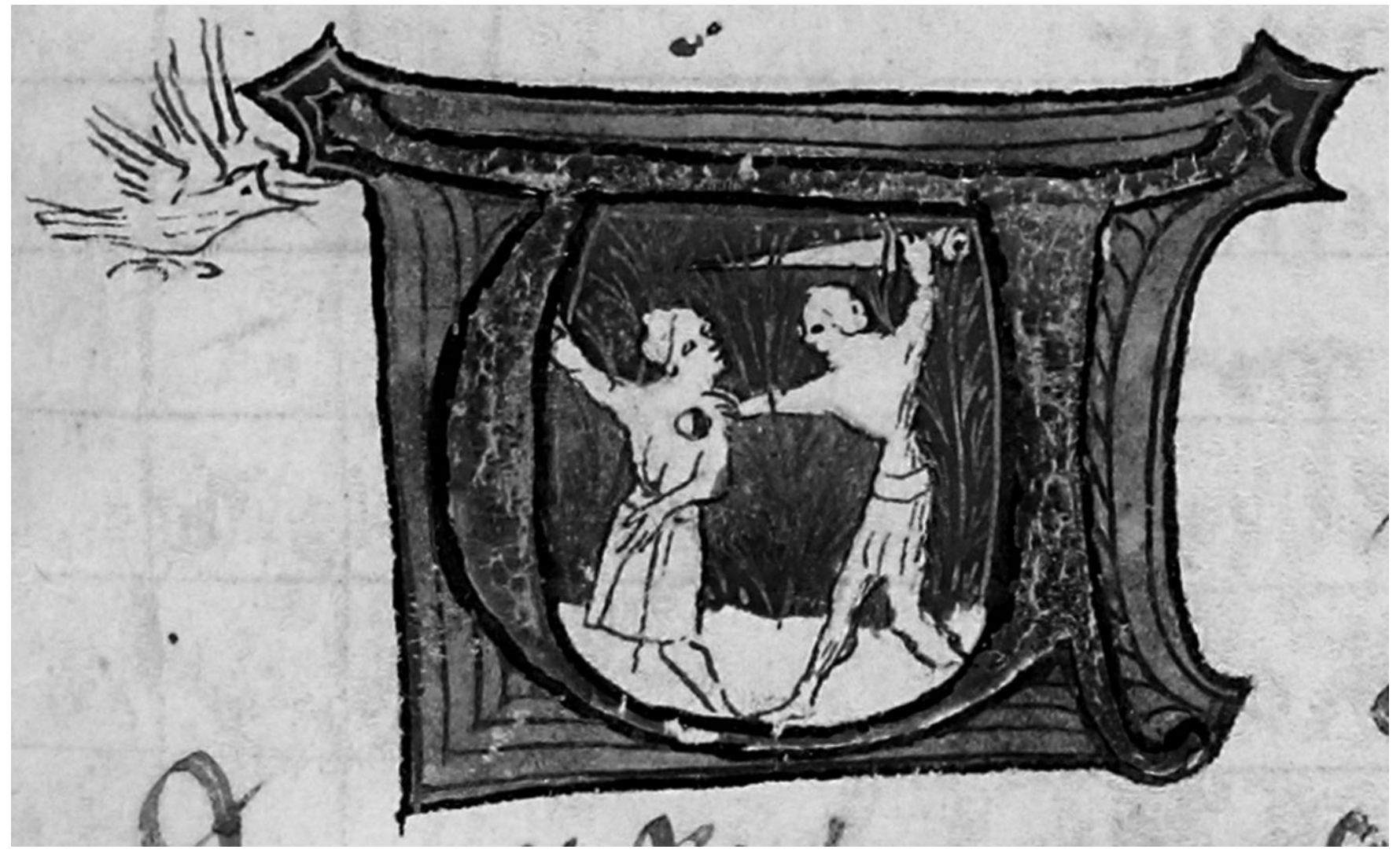

Figure 10. Fable of the murdered Jew, fol. 31r, Isopet I, made in Burgundy, ca. 1380s, Paris, Bibliothèque nationale de France, MS fr. 1595 (photo: () Bibliothèque nationale de France). See the electronic edition of Gesta for a color version of this image.

Four additional illuminations of the fable, all Burgundian, appear in versions of Isopet $I$, another compilation of fables based on those of Walter of England..$^{59}$ The three earliest, now in London, Paris, and Brussels, have closely related texts that mention several historical figures, including the dedicatee, Jeanne of Burgundy, wife of King Philip VI of France. ${ }^{60}$

59. For the text of Isopet I, see Bastin, Recueil général des Isopets, 1 (1929): 312-15.

60. These manuscripts are Brussels, Bibliothèque royale de Belgique, MS 11193; BnF, MS fr. 1594; and London, British Library, Add. 33781. For these, see McKenzie and Oldfather, Ysopet-Avionnet, 376-88 (for date, 25-52); Marguerite Debae, La bibliothèque de Marguerite d'Autriche: essai de reconstitution d'après (Louvain: Peeters, 1995), 223-26; Zago, Owen, and Serwatka, "Jew and the King's Cup-Bearer," 223-24; Busby, Codex and Context, 219-22; and Boivin, Naissance de la fable en français. According to the latter (419-46), the compiler may have been Jean de Chavenges, adviser to the Parlement of Paris. Others suggest that the compiler might have been a woman: McKenzie and Oldfather, Ysopet-Avionnet, 32-33; and Bastin, Recueil général des Isopets, 1:xxxvii. The version in Brussels has the best claim to being the presentation copy, since much of the Burgundian library entered the Royal Library in Brussels. Camille Gaspar and Frédéric Lyna, Les principaux manuscrits à peintures de la Bibliothèque royale de Belgique (Brussels:
These names enable us to date the composition of the text to 1339-48, and the illuminations are assigned to the same period, or perhaps a year or two later. The fourth manuscript, probably produced in the 1380 s, is today in Paris. Unlike the narrative approach of the image from Franche-Comte, all four Burgundian illuminations show only one scene, the most dramatic moment of the story, when the assailant draws his sword and is about to strike his target. Elaborating Walter's text, the author of Isopet I states that when the two protagonists were passing through the woods, the Jew lost trust in the servant and asked to follow him so that he might watch him closely, but the servant refused. All four images show the next moment, one of great dramatic tension, when the assailant comes from behind and raises his sword to kill the Jew, who gestures toward the birds that will avenge his death.

In one version, a complex drama is visible despite being confined within the outlines of an initial (Fig. 10). The Jew, clearly marked as such by his circular badge, raises his right hand to point to the birds that hover in the margin. He si-

Bibliothèque Royale Albert 1er, 1987), 307-10; and Busby, Codex and Context, 220.

$116:$ Gesta v55n1, Spring 2016 


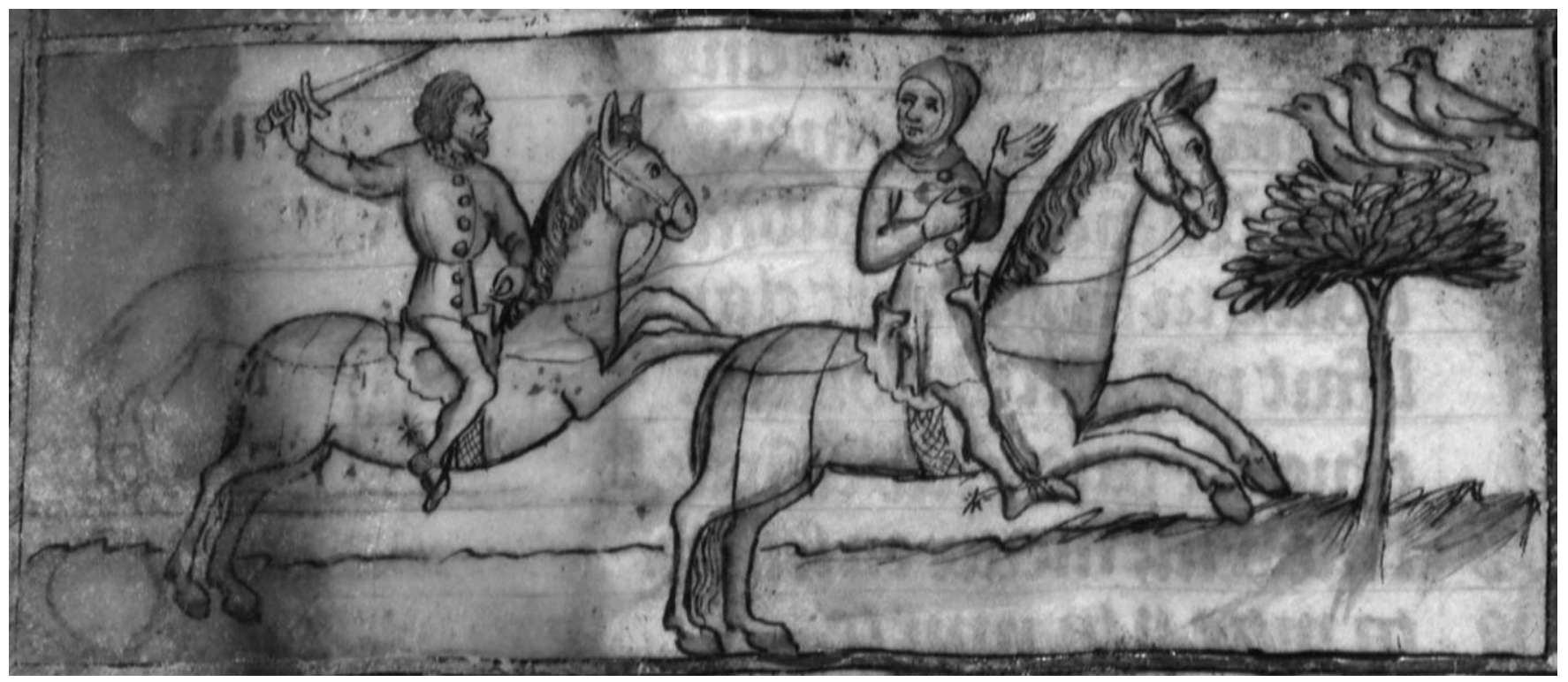

Figure 11. Fable of the murdered Jew, fol. 75v, Isopet I, made in Burgundy, ca. 1339-50, Paris, Bibliothèque nationale de France, MS fr. 1594 (photo: () Bibliothèque nationale de France). See the electronic edition of Gesta for a color version of this image.

multaneously turns back to look at his assassin, who vigorously steps forward, steadying the Jew with one hand while readying his sword with the other. Again the artist has planted seeds of sympathy for the Jew, who is shown as unarmed and about to be stabbed in the back. In another illumination, the assassin's horse leaps up, highlighting the pitched drama of this climactic scene (Fig. 11). ${ }^{61}$ Once more the Jew is marked by a badge on his chest and is in no way denigrated; by contrast, all the Burgundian miniatures make clear the treachery of the servant.

These illuminations parallel two changes introduced into the text of Isopet I: the focus on this dramatic moment and the fleshing out of the two main characters. The poet greatly expanded the fable, increasing the number of lines from twentyfour in Walter's original to eighty-two in Isopet $I^{62}$ The servant is now characterized as straying far from societal norms in his greed, his disobedience to his lord, his foolishness, and his treacherous acts of theft and murder. The Jew, by contrast, is portrayed in the text as dignified, polite, and truthful. Similarly, in the illumination in London, even though the Jew is associated with a large coffer that indicates his wealth and is clearly identified as Jewish by his circular badge, his

61. Unlike Jews who lived in Muslim lands, those who lived under Christian control were permitted to ride horses. See, for example, Yom-Tov Lewinsky, "Games," in Encyclopaedia Judaica, ed. Michael Berenbaum and Fred Skolnick, 2nd ed. (Detroit: Macmillan Reference USA, 2007), 7:370-73. 225.

62. Zago, Owen, and Serwatka, "Jew and the King's Cup-Bearer," features are normative, and he wears a long garment (Fig. 12). It is the servant who wears shorter clothes, denoting lower status, and his facial features are bestial. Furthermore, the coffer rests between the servant and the Jew, as if to indicate that it is the reason for the murder, and the servant seems to take possession of it since his right leg overlaps it. As Zago, Owen, and Serwatka conclude, "If the standing of the [servant] is diminished in this text, that of the Jew is enhanced." 63 The fable ends with the statement that no man can defend the cupbearer from his death sentence.

Zago, Owen, and Serwatka propose that the inclusion of this fable in manuscripts from Franche-Comte and Burgundy was not accidental. They observe that it did not appear in England or France after the expulsion of the Jews and argue that when the Jews were expelled from France, many fled east, to Franche-Comté and Burgundy, where they were welcomed and protected as a good source of revenue. ${ }^{64}$ But these authors paint an overly rosy picture of Jewish life at the time when these manuscripts were produced. In Franche-Comté in the late thirteenth and early fourteenth century, Jewish existence was precarious, and privileges granted Jews varied depending on date and locality. ${ }^{65}$ For example, although Jews in that

\section{Ibid., 226}

64. Ibid., 224, 226, 229, 231.

65. J. Morey, "Les Juifs en Franche-Comté au XIVe siècle," Revue des études juives 7 (1883): 1-39; Bernhard Blumenkranz, "FrancheComté," in Berenbaum and Skolnick, Encyclopaedia Judaica, 7:172; and Annegret Holtmann, Juden in der Grafschaft Burgund im Mittelalter (Hannover: Hahn, 2003).

Complicating Medieval Anti-Semitism $\sim 117$ 


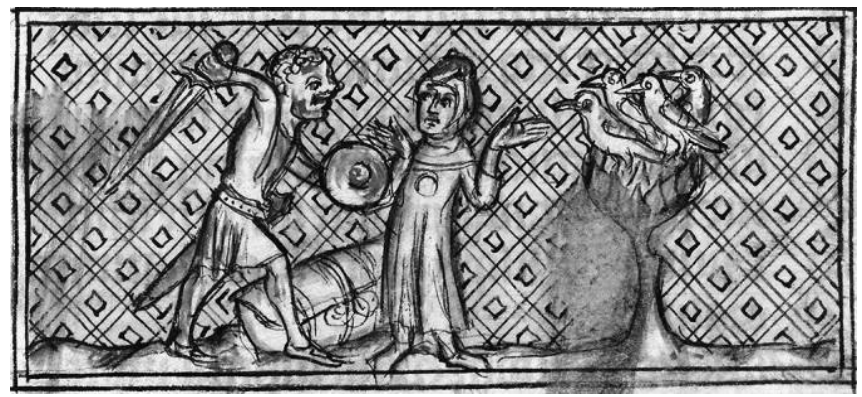

Figure 12. Fable of the murdered Jew, fol. 94r, Isopet I, made in Burgundy, ca. 1339-50, London, British Library, MS Add. 33781 (photo: () British Library Board). See the electronic edition of Gesta for a color version of this image.

county were unaffected by the expulsion of Jews from the French kingdom in 1306, they were included in the expulsion edict of $1322 .{ }^{66}$ Similarly, a document of 1296 indicates that some areas permitted Jewish residence, whereas others did not. ${ }^{67}$ In return for the payment of road tolls, two charters enacted in the 1290s guaranteed Jews a series of privileges, including the right of safe passage and protection from violent attacks-the very rights that the servant in the fable ignores. ${ }^{68}$ Yet some segments of the population vociferously condemned usury and wished to restrict the activities of Jews. Violence erupted in Franche-Comté in the 1320s, when a popular movement, composed largely of peasants, massacred Jews. ${ }^{69}$ In the same decade Jews were ordered to leave the county, although it is unclear how many did, since by the 1330s the number of Jews there had increased. ${ }^{70}$ Zago, Owen, and Serwatka go too far when they suggest that Jews were uniformly welcomed in Franche-Comté, but they appear to be justified in concluding that the "dissemination of the fable was intended to constitute a kind of policy statement in favor of the Jewish community in Franche-Comté."71

Jews went to the county only very late in the thirteenth century, when the need for moneylenders, including Jews, became especially acute. ${ }^{72}$ Noblemen there had revolted against Count Otto IV of Burgundy after he signed a treaty in 1295 ceding the county to his daughter Jeanne as a dowry and designating her husband, Philip IV, king of France, as its adminis-

66. Bernhard Blumenkranz, Les Juifs en France: écrits dispersés (Paris: Belles Lettres, 1989), 64; and Holtmann, Juden in der Grafschaft Burgund, 66.

67. Blumenkranz, Les Juifs en France, 65.

68. Morey, "Les Juifs en Franche-Comté," 4-5.

69. Ibid., 11.

70. Ibid., 11, 13.

71. Zago, Owen, and Serwatka, "Jew and the King's Cup-Bearer," 227.

72. Jordan, French Monarchy and the Jews, 218. trator. ${ }^{73}$ Civil warfare continued until 1301, despite mounting debts on both sides of the conflict. Because of their opposition to Otto and their need for funding, many aristocrats opposed the count's French-leaning policies, including those that were anti-Jewish. The debt left to succeeding generations and the cost of the continuing violence prolonged the need for loans well into the fourteenth century. For these reasons, the text and image of the murdered Jew must be seen in the context of the struggle between the count and the king, on one side, and the lower lords, on the other. The tale of an innocent Jew who is unfairly attacked may have served to support noblemen who argued that Jews should be permitted to stay in FrancheComté. In doing so, it inverted the original topos of the tale, a king's desire to protect his Jews.

Jews in Burgundy also had a perilous existence. Although a massive emigration occurred in 1321 or 1322 , by the 1330 s eighty-five Jewish households are recorded there. ${ }^{74}$ Jeanne of Burgundy, the dedicatee for the three earliest Burgundian fable books that include the story of the murdered Jew (Figs. 1011), was an avid collector of a wide range of manuscripts, and it would be natural for a writer to try to obtain her patronage. ${ }^{75}$ The dedication to her suggests several purposes for the fable book. It was to be used for entertainment, especially in the winter when it is difficult to enjoy outdoor pleasures, and for instruction, particularly for the young ("aux juesnes gens"). ${ }^{76}$ We cannot be certain why the tale of the murdered Jew was included in a manuscript dedicated to the queen, but it was probably intended, at least in part, to encourage her to tolerate a Jewish presence in her territories.

The case is clearer for the fourth Burgundian illumination of the fable, created in the 1380s (Fig. 10). In 1374 Duke Philip the Bold granted privileges to Jews, although he limited the number of families who could live in Burgundy to twelve; in 1380 he increased the number to twenty. Despite a popular outcry and calls for expulsion, the duke granted Jews privileges again in 1384 and increased their number to fifty-two families. Yet in 1394, before the end of their twelve-year term, all Jews were expelled. ${ }^{77}$ It makes sense, then, that during the period in which the duke of Burgundy welcomed Jews to the

73. Ibid., 220; Morey, "Les Juifs en Franche-Comté," 7; and Holtmann, Juden in der Grafschaft Burgund, 35.

74. Holtmann, Juden in der Grafschaft Burgund.

75. Anne D. Hedeman, The Royal Image: Illustrations of the "Grandes Chroniques de France," 1274-1422 (Berkeley: University of California Press, 1991), 291-92n19; June Hall McCash, The Cultural Patronage of Medieval Women (Athens: University of Georgia Press, 1996), 14; and Boivin, Naissance de la fable en français, 344.

76. Busby, Codex and Context, 220.

77. Roger S. Kohn, "Burgundy," in Medieval Jewish Civilization: An Encyclopedia, ed. Norman Roth (New York: Routledge, 2003), 121-23; Bernard Blumenkranz, "Burgundy," in Berenbaum and

$118:$ Gesta v55n1, Spring 2016 
county, a book produced there would portray a Jew as an innocent who is unfairly attacked and in need of protection.

\section{German and Swiss Images}

German-language fable books were extremely popular, especially Ulrich Boner's Der Edelstein, a collection of one hundred tales that were derived in large part from those attributed to Walter of England. ${ }^{78}$ Boner, a Dominican preacher from Bern, composed his comical and down-to-earth fables in Middle High German about 1349-50. Images of the story of the murdered Jew appear in southern Germany and Switzerland in eleven fifteenth-century manuscripts of Der Edelstein and in its first printed edition. ${ }^{79}$ By 1461 Der Edelstein had become so popular that Albrecht Pfister of Bamberg decided to publish it as the first book with movable type to be illustrated with woodcuts. ${ }^{80}$ Despite their popularity, Boner's fables never developed a fixed iconography. Illuminations of the murdered Jew show a range of subjects, including the murder, the serving of the partridge, and the hanging of the assassin on the gallows. Although a few images reinforce the negative stereotype of the Jew by showing him clutching money, most represent him in a sympathetic light. ${ }^{81}$

In a manuscript today in St. Gall, which was produced for an unknown patron in northern Switzerland in the third quarter of the fifteenth century, the Jew is not denigrated in any way (Fig. 13). ${ }^{82}$ In the miniature, which precedes and

Skolnik, Encyclopaedia Judaica, 4:290-91; and Holtmann, Juden in der Grafschaft Burgund, 83-84, 115.

78. Ulrich Boner, Der Edelstein von Ulrich Boner, ed. Franz Pfeiffer (Leipzig: Göschen, 1844); and Robert Henri Blaser, "Ulrich Boner, un fabuliste suisse du XIVe siècle" (PhD diss., Université de Paris, 1949).

79. Hella Frühmorgen-Voss et al., Katalog der deutschsprachigen illustrierten Handschriften des Mittelalters (Munich: Beck, 2012), vol. 4, no. 1, pt. 3, esp. 203.

80. This edition illustrates our fable through two images, one showing the murder scene, the other the servant presenting the partridge. For them, see Ulrich Boner, Der Edelstein: Faksimile der ersten Druckausgabe Bamberg 1461, 16. I Eth. $2^{\circ}$ der Herzog August Bibliothek Wolfenbüttel, ed. Doris Fouquet-Plümacher (Stuttgart: Müller und Schindler, 1972), 2:101-3; and Frühmorgen-Voss et al., Katalog der deutschsprachigen illustrierten Handschriften, 203, 267-69. For this and other printed fable books, see also Fabula docet: illustrierte Fabelbücher aus sechs Jahrhunderten; Ausstellung aus Beständen der Herzog August Bibliothek Wolfenbüttel und der Sammlung Dr. Ulrich von Kritter (Wolfenbüttel: Die Bibliothek, 1983), 105-12.

81. Those showing the Jew grasping a purse or sack of money include the printed edition and Dresden, Sächsische Landesbibliothek, Staats- und Universitätsbibliothek, MS Dresd. M 67, fol. 132v.

82. Frühmorgen-Voss et al., Katalog der deutschsprachigen illustrierten Handschriften, 203, 249-53. This illumination appears in a version of Der Edelstein that centuries later became part of a

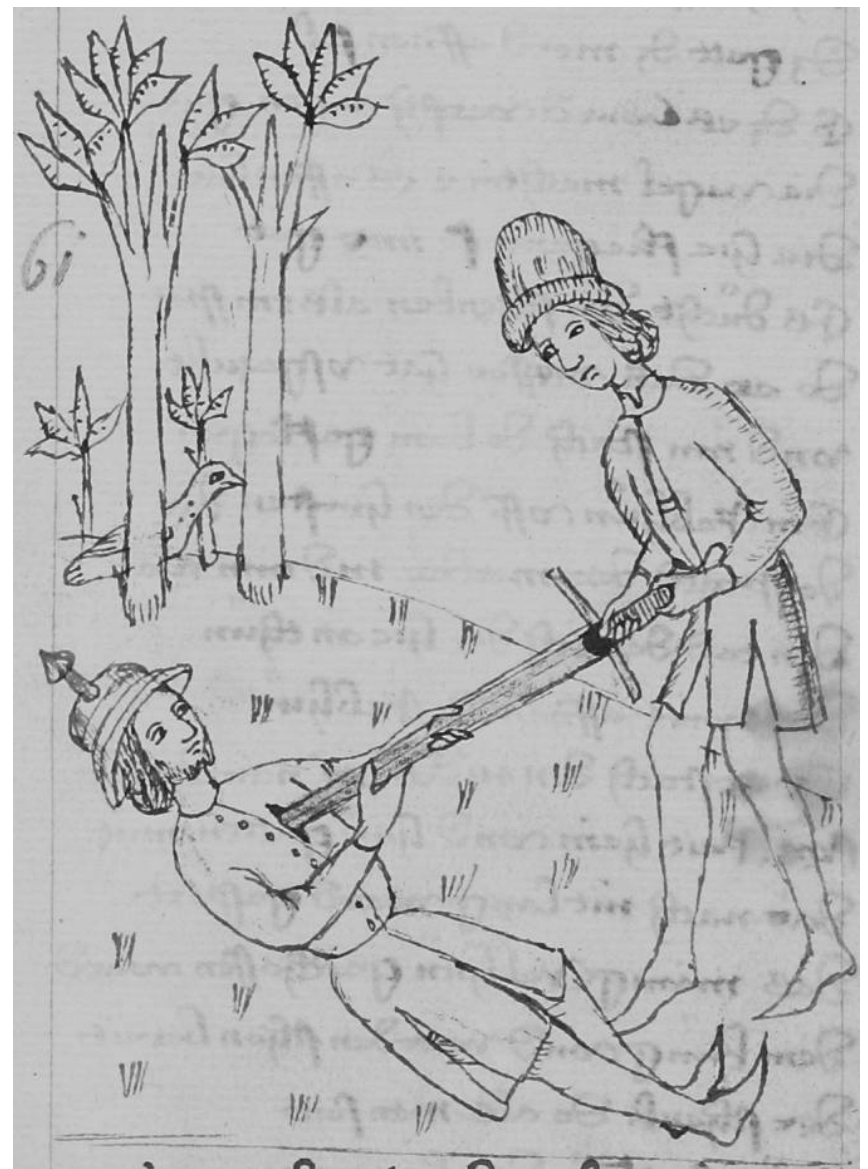

Figure 13. Fable of the murdered Jew, p. 55, Der Edelstein by Ulrich Boner, third quarter of fifteenth century, St. Gall, Stiftsbibliothek, cod. Sang. 643 (photo: Stiftsbibliothek St. Gallen).

thereby introduces the fable, the victim is identified as Jewish by his beard and pointed hat, but in many ways he resembles his assailant. Both are young, slender youths of about the same height who wear similar knee-length slitted garments. In this version, the servant stabs the unarmed Jew in an isolated place, a meadow bordered by trees, which highlights the devious nature of the attack. Garnering further sympathy for the Jew is his act of grasping with both hands the blade of his attacker's long sword. This might have been interpreted as a tragic, desperate attempt to dislodge the weapon from his chest, or as a heroic martial-arts move, the so-called murder stroke, which involved seizing the blade of one's opponent's sword in order to gain control of it and then using it against him. This action is described in Hans Talhoffer's popular fifteenth-century martial-arts treatise, which was reproduced

miscellany with four other manuscripts: a collection of anonymous Swiss poems, a chronicle of the city of Zurich, a nineteenth-century philological study of the manuscript of Der Edelstein in St. Gall, and a list of noble names. Ibid., 252.

Complicating Medieval Anti-Semitism $\sim 119$ 


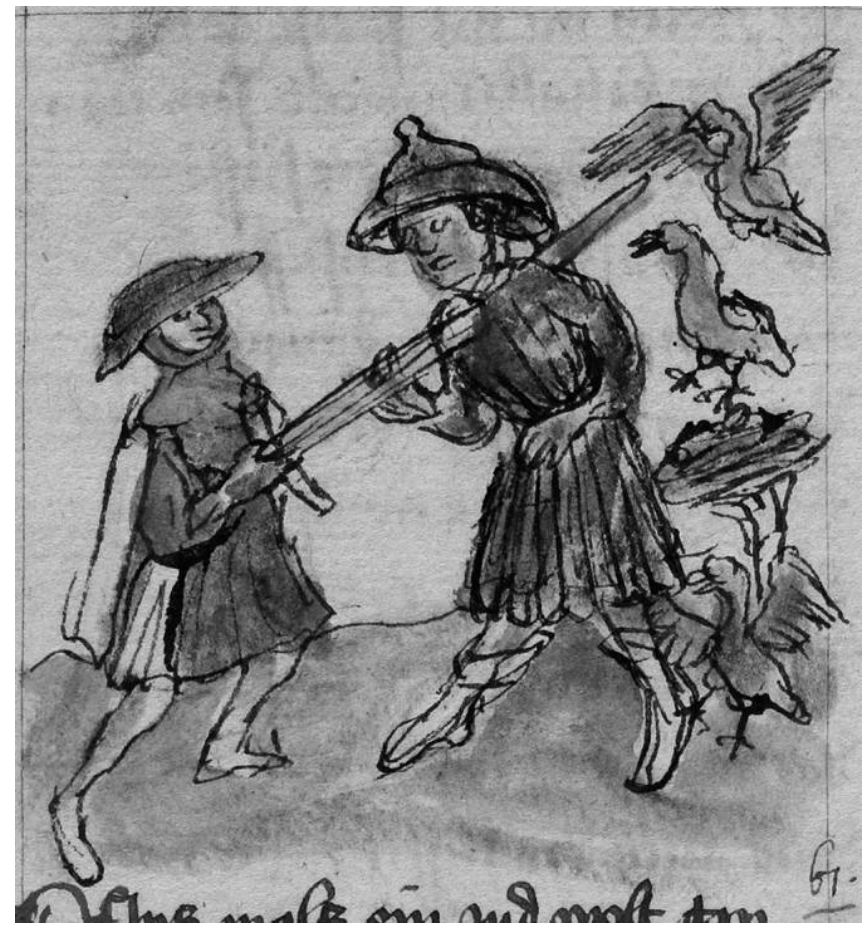

Figure 14. Fable of the murdered Jew, fol. 33v, Der Edelstein by Ulrich Boner, Augsburg, 1443-49, Heidelberg, Universitätsibliothek, cod. Pal. germ. 314 (photo: Heidelberg University Library). See the electronic edition of Gesta for a color version of this image.

many times, including in an illustrated Swabian manuscript of $1467 .{ }^{83}$ In a volume of Der Edelstein produced in Augsburg in 1443-49, an illumination that precedes the accompanying fable shows the Jew similarly grabbing the blade of the sword, although this time with just one hand (Fig. 14) ${ }^{84}$ Unlike the manuscript in St. Gall, the Jew is here the star of the scene since he is much larger than the servant and occupies the center of the composition. On the right, four fluttering birds register the pitched drama of the assault.

A different, but similarly sympathetic, approach is adopted in a manuscript created in Augsburg in 1449 and written in a Swabian dialect, which includes two illuminations of the fable. ${ }^{85}$ The first, which precedes the tale, shows the murder taking place in a clearing in a dense forest (Fig. 15). As a bird flies

83. Hans Talhoffer, Medieval Combat: A Fifteenth-Century Illustrated Manual of Swordfighting and Close-Quarter Combat, trans. and ed. Mark Rector (London: Greenhill Books, 2000), esp. n. 17.

84. Frühmorgen-Voss et al., Katalog der deutschsprachigen illustrierten Handschriften, 203, 228-31.

85. Ulrike Bodemann, Ulrich Boner, Der Edelstein (Universitätsbibliothek, Cod. I.3.2 ${ }^{\circ}$ ): kodikologische und kunsthistorische Beschreibung; mit einem Anhang, des Teufels Netz, Sibyllenweissagung, monochrome Mikrofiche-Edition (Munich: Lengenfelder, 1987); and Frühmorgen-Voss et al., Katalog der deutschsprachigen illustrierten Handschriften, 203, 206-9.

$120:$ Gesta $\quad$ v55n1, Spring 2016

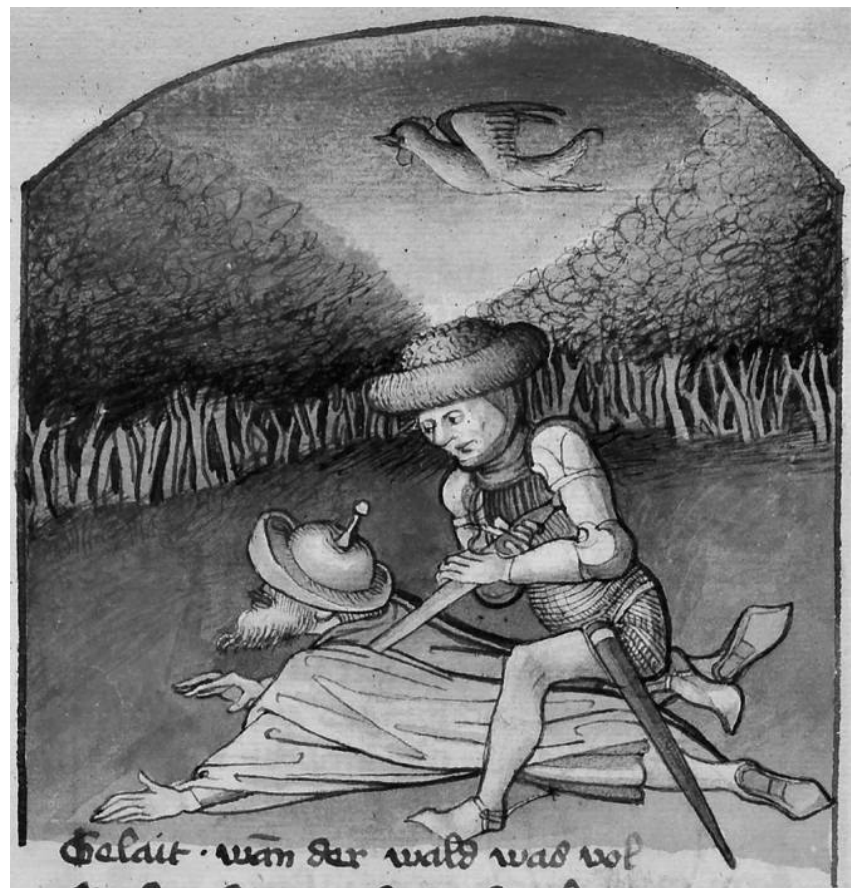

Figure 15. Murder of the Jew, fol. 63v, Der Edelstein by Ulrich Boner, Augsburg, 1449, Augsburg, Universitätsbibliothek, cod. I.3.2 III (photo: Universitätsbibliothek Augsburg). See the electronic edition of Gesta for a color version of this image.

overhead, the servant plunges his sword into the Jew, who is identifiable by his beard and pointed hat. The victim's agony is expressed through his raised head, arched back, grimacing expression, and convulsing hands. The illuminator underscores the treacherous and cowardly nature of the crime by depicting the servant straddling the unarmed Jew while stabbing him in the back. The second illumination is placed midway through the text of the fable, just below the line that describes the servant presenting the king with the partridge and remembering the Jew's prophetic words (Fig. 16). The murderer, now bareheaded, barefoot, and dressed in the simple undyed garment of the condemned criminal, sits on the ground with his wrists bound; beside him, a monk helps him repent his sins. The hangman readies the ladder for the murderer's ascent, while the rope by which he will hang lies nearby on the ground. The empty gallows, which takes up half the composition, is ominously silhouetted against the sky and serves as a powerful reminder of the murderer's fate. These illuminations reinforce the text, which condemns the murderer's greed, states that it led him to sin, and notes that the consequence must be his execution, since the wages of sin is death, "as the Holy Scriptures teach us." ${ }^{\prime 6}$

86. Pfeiffer, Der Edelstein von Ulrich Boner, 108, line 8: “als uns lêrt der heiligen wort." 


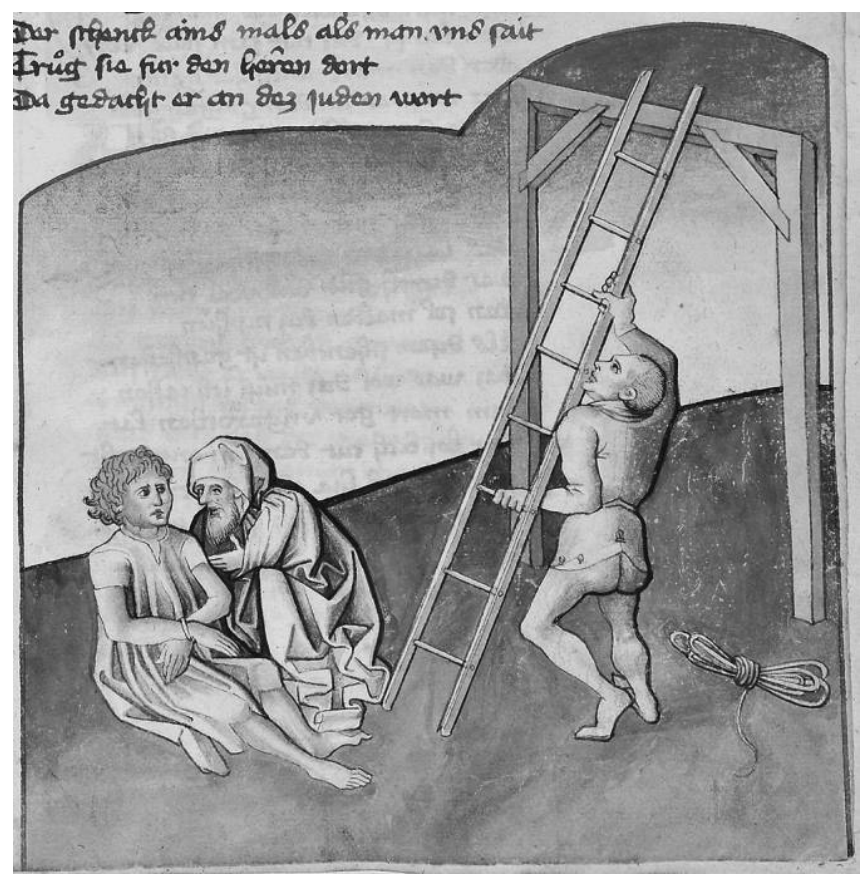

Figure 16. Preparation for hanging, fol. 64r, Der Edelstein by Ulrich Boner, Augsburg, 1449, Augsburg, Universitätsbibliothek, cod. I.3.2 III (photo: Universitätsbibliothek Augsburg). See the electronic edition of Gesta for a color version of this image.

Jews were permitted to live in southern Germany and Switzerland, but their lives were precarious. They were expelled from city after city: Basel in 1397, Freiburg in 1424-25, Zurich in 1436, Augsburg in 1439, Bamberg in 1478, and Ulm and Nuremberg in 1499. Similarly, aristocratic lords expelled Jews; the Bavarian princes did so in 1442-50. Norman Roth terms the fifteenth century in Germany the "century of persecution" for the Jews. ${ }^{87}$ Yet the territorial and political complexity of this region could afford opportunities as well, for when one area expelled Jews, another would permit them to settle.

Most of the original owners of the manuscripts of Der Edelstein are unknown, but the copy just discussed was in the library of Count Wilhelm I von Oettingen by 1462 (Figs. 1516). ${ }^{88}$ By contrast, a manuscript today in Heidelberg, which was also produced in Augsburg at roughly the same time (between 1443 and 1449), was in the library of the merchant

87. Norman Roth, "Germany," in Roth, Medieval Jewish Civilization, 293-304, at 302-4 (quote on 302). For Jews in Swabia, see also Michael Brenner and Sabine Ullmann, eds., Die Juden in Schwaben (Munich: Oldenbourg, 2013).

88. Brenner and Ullmann, Die Juden in Schwaben, 7; and Ulrich Boner, Der Edelstein: öffentliche Bibliothek der Universität Basel, Handschrift A.N.III.17; mit einer Einführung in das Werk von Klaus Grubmüller; kodikologische und kunsthistorische Beschreibung von Ulrike Bodemann (Munich: Lengenfelder, 1987), 12, 17-18.
Sigismund Gossembrot by 1449 (Fig. 14) ${ }^{89}$ Gossembrot came from an old patrician family from Augsburg, studied at the University of Vienna, served on the city council in the 1440s, and became mayor of Augsburg in 1458. A merchant with ties to the Fuggers who traveled for commercial reasons to Italy, he was also a humanist who assembled an impressive library. In short, the German and Swiss versions of Der Edelstein bridge the gap between the earlier aristocratic manuscripts from Franche-Comté and Burgundy, which express feudalistic ideals and oppose royal policies, and the fifteenth-century Tuscan manuscripts, which articulate mercantile values.

\section{Tuscan Illuminations}

About twenty manuscripts produced in Tuscany derive from a single prototype, the Esopo volgarizzato per uno da Siena, which was written in a Tuscan dialect in the late fourteenth century. ${ }^{90}$ The text is believed to have been composed by a merchant, and this dramatically affected the style and content of the tales. ${ }^{91}$ Based on Walter of England's collection of fables, the Esopo volgarizzato appealed to mercantile tastes. Merchants wanted their stories not only to fulfill the usual goals of a short, entertaining tale with a clear moral but also to include references to trade, realistic details, quick-paced narrative, and lively prose.${ }^{92}$ Most of the prosperous, educated merchants who owned these manuscripts were citizens of the Florentine Republic with close ties to both the Medici and humanists, and the Esopo volgarizzato reflects both mercantile values and civic ethics. The anonymous author of this collection of fables also modified Walter's tales by adding to the distichs that concluded each fable two new morals, one spiritual and the other secular.

In the fable of the murdered Jew, the plot remains the same. The servant is still characterized as someone from the king's inner circle, one of his most trusted attendants (donzello). In

89. Friedrich Roth, “Gossenbrot, Sigismund," in Allgemeine deutsche Biographie, ed. Historischen Kommission bei der Königl. Akademie der Wissenschaften (Leipzig: Duncker \& Humblot, 1904), 49:475-77; and Friedrich Blendinger, "Gossembrot, Sigmund," in Neue deutsche Biographie, ed. Historischen Kommission bei der Bayerischen Akademie der Wissenschaften (Berlin: Duncker \& Humblot, 1964), 6:648-49.

90. For the most recent discussion of these books, see Federico Botana, "Family Wisdom in Quattrocento Florence: The Benci Aesop (Florence, Biblioteca Nazionale Centrale MS II.II.83)," Journal of the Warburg and Courtauld Institutes 75 (2012): 53-92.

91. Zago, Owen, and Serwatka, "Jew and the King's Cup-Bearer," 234-35; and Vittore Branca, ed., Esopo toscano: dei frati e dei mercanti trecenteschi (Venice: Marsilio, 1989), 53.

92. Vittore Branca, ed., Merchant Writers of the Italian Renaissance, trans. Murtha Baca (New York: Marsilio, 1999), ix, xvii-xviii, xxv, xxx, xxxii, xxxiii, xli, xliv.

Complicating Medieval Anti-Semitism $:$ 
the title of the story he is called a mariscalco, or high court official. ${ }^{93}$ The body of the fable describes him as "the most intimate and valuable one that he [the king] had, who served him in his room." ${ }^{4}$ The Jew, as usual, is a wealthy but sympathetic victim. As Zago, Owen, and Serwatka observe, the Tuscan version of the tale introduces into its first sentence the verb guadagnato (earned) to suggest that the Jew earned his money; in other words, he acquired it the same way other merchants did. Furthermore, the text emphasizes the Jew's fear of being robbed as he enters the forest. The same authors note that in the first seven lines of the tale the merchant's apprehension is mentioned five times. ${ }^{95}$ One sentence states, for example, that the Jew is weighed down as much by fear as by his heavy load. ${ }^{96}$ This same fear-of being robbed when alone in a distant land-would have been shared by many Christian merchants. Zago, Owen, and Serwatka justly conclude that the merchants who composed the audience for this tale would have identified with the Jew. ${ }^{97}$ In fact, in one manuscript in Florence, the Jew is so assimilated to the concept of the merchant that initially the first line of the fable read, "Once there was a merchant," rather than the usual "Once there was a Jew." ${ }^{\text {"98 }}$ Only later was a correction made and the word Giudeo inserted alongside (Fig. 17).

The secular moral that was added at the end of the tale strongly criticizes the servant. It reads, "By the attendant is 236.

93. Zago, Owen, and Serwatka, "Jew and the King's Cup-Bearer,"

94. For the accompanying text, see Claudio Ciociola, ed., L'Esopo di Udine: cod. Bartolini 83 della Biblioteca arcivescovile di Udine (Udine: Casamassima, 1996), 155-58: "più segreto et ch/aro che gli s(e)rvisse i(n) chamera" (156). 236.

95. Zago, Owen, and Serwatka, "Jew and the King's Cup-Bearer,"

96. For the original, see Ciociola, L'Esopo di Udine, 155: "e non era meno charichato del peso de la paura che del peso dello avere." In sixteenth- and seventeenth-century northern Italy, some Jews sought and won an exemption from wearing the obligatory Jewish dress or badge when they traveled, probably in an attempt to protect themselves from harm. Brian S. Pullan, The Jews of Europe and the Inquisition of Venice, 1550-1670 (Oxford: Blackwell, 1983), 155; and Don Harrán, Salamone Rossi: Jewish Musician in Late Renaissance Mantua (Oxford: Oxford University Press, 1999), 16, 18, 25, 246. Alfred Rubens notes that travelers and the wealthy were often exempted from wearing the badge: Rubens, A History of Jewish Costume, enlarged ed. (London: Weidenfeld \& Nicolson, 1973), 82, 86. Similarly, see Norman Roth, "Badge, Jewish," in Roth, Medieval Jewish Civilization, 67-70, at 68. The threat was so great that Jewish authorities even permitted traveling Jews to disguise themselves as priests, according to Israel Abrahams, The Book of Delight, and Other Papers (New York: Arno Press, 1980), 125.

97. Zago, Owen, and Serwatka, "Jew and the King's Cup-Bearer," 236.

98. Ibid. understood each perfidious and treacherous man who under cover of loyalty betrays his duty, and acts harmfully and disloyally." ${ }^{99}$ By contrast, it describes the Jew more favorably: "by the Jew is understood each man who trusted unconditionally and finds himself cheated." ${ }^{100}$ Here the Jew is seen as a merchant who foolishly placed his trust in the servant. The mercantile lesson is clear: if you travel with large sums of money, be careful whom you trust. In the spiritual moral, the Jew is interpreted as "every man who unconditionally trusts his confessor." 101 It is astonishing that the Jew has become "every man" rather than an outsider who adheres to another faith.

The illustrations express many of the same ideas as the text. Three manuscripts share a similar composition. The one in Udine was copied and illustrated in 1449 by a Florentine magistrate, Francesco di Cambio Orlandi, who came from a wealthy family and was a friend of Cosimo de' Medici (Fig. 18). It emphasizes the secular moral by showing the Jew, on the right, carrying a heavy sack of money; he approaches the servant and offers to pay him for protection. ${ }^{102}$ Raising his hammer above his anvil, the servant appears to be forging a sword-the weapon with which he will kill the Jew. Yet the Jew seems oblivious, and this appears to be the artist's main point. The focus is on the anxieties of wealthy merchants, not the concerns of medieval kings. Even though the Jew is bearded and serves as an example of a foolish businessman, his dress is nearly identical to the servant's and he is not visually denigrated in any way.

A drawing at Harvard University, which was added in the fifteenth century to a late fourteenth-century Sienese manuscript by someone who was clearly not a professional artist, adopts a different approach (Fig. 19). ${ }^{103}$ Here a graphic

99. Ibid., 238: "Per questo donzello s'intende ciascuno uomo malvagio e fello a che pura fede di leanza tradisce e fa dannaggio e misleanza."

100. Ibid.: "E per lo giudeo ciascuno che s'è fidato liberamente e truovasi ingannato."

101. Ibid., 237: "ciascuno uomo liberamente si fida nel confessor."

102. For this manuscript, see Branca, Esopo toscano. For Francesco, see Claudio Ciociola, "Francesco di Cambio," in Ciociola, L'Esopo di Udine, 235-301. The coins in the sack are clearly visible in a version copied by Piero dei Rici (Florence, Biblioteca Riccardiana, MS 2805, fol. 121r, dated 1463). Another manuscript that shows this composition was also copied by Piero dei Rici in 1463 or earlier (Florence, Biblioteca nazionale centrale, MS XXI.87).

103. For this manuscript, see Livres anciens et modernes manuscrits et imprimés .. . (Milan: Hoepli, 1954), 20-22, no. 26; Paul Oskar Kristeller, Iter Italicum: A Finding List of Uncatalogued or Incompletely Catalogued Manuscripts of the Renaissance in Italian and Other Libraries (London: Warburg Institute, 1990), 5:237; and Roger S. Wieck, Late Medieval and Renaissance Illuminated Manuscripts, 1350-1525, in the Houghton Library (Cambridge, MA: Department

$122: \quad$ Gesta $\quad$ v55n1, Spring 2016 


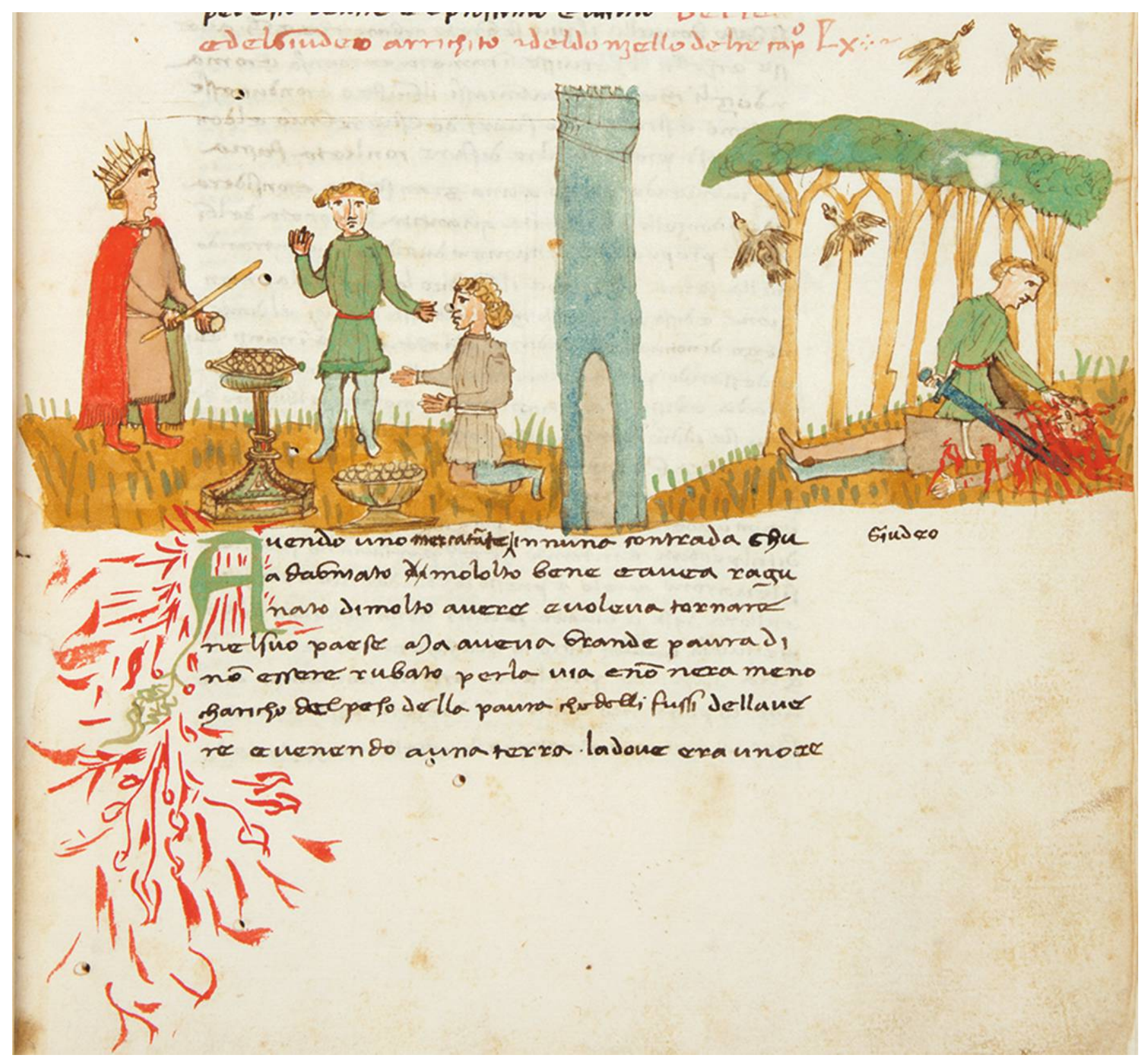

Figure 17. Filippo di Lorenzo de Benci, fable of the murdered Jew, fol. 65r, Esopo volgarizzato, 1450s, Florence, Biblioteca nazionale centrale, MS II.II.83 (photo: by concession of the Ministero dei beni e delle attività culturali e del turismo/Biblioteca nazionale centrale di Firenze; further reproduction prohibited).

image of the deceased shows him lying on the ground, his decapitated head resting some distance from his body. His assassin walks nonchalantly off to the right, a long sword at his side, while three birds fly before him. The dead Jew is not

of Printing and Graphic Arts, Harvard College Library, 1983), 135. Livres anciens et modernes (22) states that Hebrew inscriptions in this manuscript suggest that the Italian merchant who owned it may have worked with a Jewish middleman. marked as such; he has no beard, wears no Jewish badge, and his youthful face is not caricatured at all. The Jew is simply a merchant who, tragically, has been killed because he trusted unwisely. In a manuscript in Verona, the Jew, whose head lies in a pool of blood, wears the same type of clothing and has a haircut and youthful face similar to those of his assassin, who now carries off his sack of money. ${ }^{104}$

104. Verona, Biblioteca civica, MS 528-529, fol. 59v. 


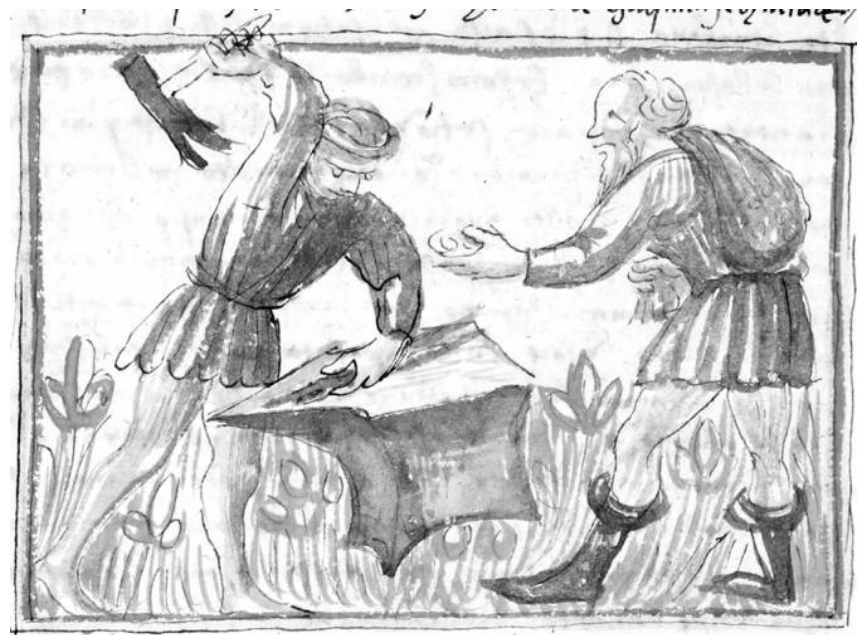

Figure 18. Francesco di Cambio Orlandi, fable of the murdered Jew, fol. 72r, Esopo volgarizzato, 1449, Udine, Biblioteca arcivescovile e Bartoliniana, MS Bartolini 83 (photo: Archivio diocesano, Udine). See the electronic edition of Gesta for a color version of this image.

The most poignant image among the quattrocento mercantile manuscripts appears in a fable book copied and illustrated by Filippo di Lorenzo Benci in the 1450s (Fig. 17). ${ }^{105}$ Filippo came from a family of successful merchants who were friendly with the humanist Marsilio Ficino and had connections to Lorenzo de' Medici. They had a large library, containing mostly vernacular, secular miscellanies. Filippo was the copyist for at least nine of these manuscripts, and he added illustrations to a few of them. He was not a professional artist, but his compositions show greater complexity than do contemporary drawings in other Tuscan fable books. ${ }^{106}$ The image for the fable of the murdered Jew depicts at the left a standing king, crowned, caped, and holding a scepter and a gold coin. He faces the kneeling Jew, and between them stands the servant, his shorter stature compared with that of the king denoting his lower status. The Jew is described as wealthy ("arricchito"), and this is underlined by the two large vessels filled with gold that are displayed in the foreground. To the right is a second scene, separated from the first by a crenellated tower. In a grove of trees that represent a forest, four birds fly away while the assailant kneels, bloody sword in hand, beside the Jew whom he has slain. The servant leans toward his victim and touches his head as blood pours from wounds to the head, neck, and side. The head of the Jew is turned so that his unseeing eyes face the viewer. Fashionably dressed in blue and pink parti-colored stockings, the Jew is certainly not denigrated. Indeed, he looks remarkably like the

105. Botana, "Family Wisdom in Quattrocento Florence."

106. Botana (ibid., 64) wonders if these drawings are copied from another manuscript rather than being Filippo's inventions. servant. They are comparably dressed, and both are shown as slim, beardless, blond youths. Furthermore, unlike the example in Udine (Fig. 18), there is no suggestion of the foolishness of the Jew, and unlike the example at Harvard (Fig. 19), Filippo creates a space for the reader to view the murder as horrific and poignant. The leaflike red forms that issue from the first letter of the fable and spill down the left margin seem to underline the bloody and tragic ending of the Jew.

Just as Jeanne of Burgundy may have used her fable book to instruct her children, so Filippo di Benci may have employed the Esopo volgarizzato to teach youngsters civic ethics and mercantile values. Federico Botana recently demonstrated that Filippo produced his book in part to educate the children in his extended family. ${ }^{107}$ His evidence is extensive, but it rests in part on manuscripts (like the one at Harvard) that are miscellanies composed of books that were often used to teach children. ${ }^{108}$ Although Botana does not discuss Filippo's image of the murdered Jew, it could easily have been used to teach future merchants. It emphasizes the value of loyalty by portraying a disloyal servant, and it dramatically conveys the need to place trust wisely by visualizing the bloody, lifeless body of a Jew lying isolated in a wood.

Two factors help explain why the fable shows a Jew in a sympathetic light as a stand-in for the figure of the Christian merchant. The first is that the tale appears in a secular book that is primarily concerned with mercantile values and civic ethics, not with religious disputations. The second is the date of the Tuscan manuscripts, which were produced from about 1380 to 1463 , at a time when Jews were viewed with relative benevolence.

Jews had migrated north from Rome in the twelfth and thirteenth centuries; their earliest attested presence in Florence was in $1304 .{ }^{109}$ As a major commercial center, Florence benefited from its Jewish moneylenders, and at first their services were acknowledged. One document, for example, requests permission for a Jewish moneylender to stay in town by noting "the financial distress that the paupers experience because of the absence of a Jewish lender." ${ }^{110}$ Maristella Botticini has observed that "Jewish lending helped households to smooth

107. Ibid., 82-92. Der Edelstein was also sometimes used to teach children. Boner, Der Edelstein: öffentliche Bibliothek der Universität Basel, 18 .

108. This book includes Seneca's De IV Virtutibus, Cato's Disticha, Pseudo-St. Bernard's Epistola a Rinaldo Chavalier and Epistola a Raymond, and Albertano of Brescia's De arte loquendi and Legenda St. Eustachii.

109. Carol Bresnahan Menning, Charity and State in Late Renaissance Italy: The Monte di Pietà of Florence (Ithaca, NY: Cornell University Press, 1993), 14.

110. Maristella Botticini, “A Tale of 'Benevolent' Governments: Private Credit Markets, Public Finance, and the Role of Jewish Lend-

$124:$ Gesta $\quad$ v55n1, Spring 2016 


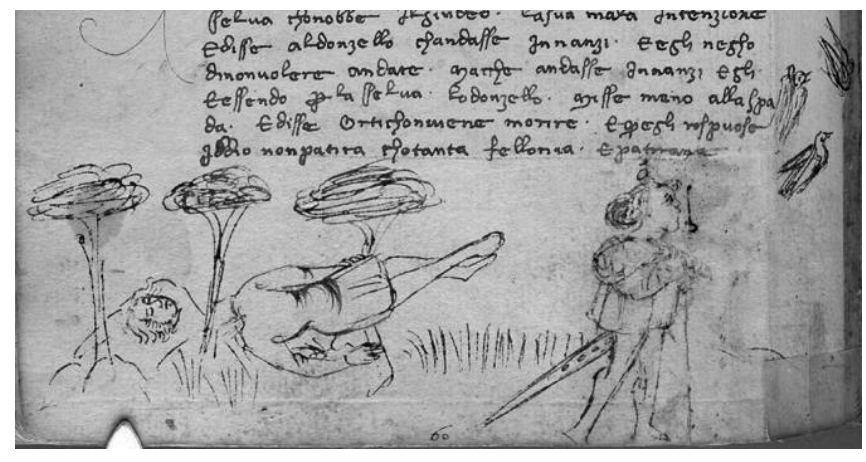

Figure 19. Fable of the murdered Jew, fol. 56v, Esopo volgarizzato, fifteenth-century drawing added to fourteenth-century manuscript, Harvard University, Houghton Library, MS Typ 479 (photo: Houghton Library, Harvard). See the electronic edition of Gesta for a color version of this image.

consumption, buy working capital, and provide dowries for daughters." ${ }^{\prime 11}$ Jews lent money to a wide range of Florentines, from peasants to the wealthy, and to the commune itself. As Michael Dean Crews concludes, "These services were vital to the rapidly developing economy of fifteenth-century Tuscany."112 Because Jewish lending relied on a widespread network of family and friends, it was less subject to unpredictable local economic conditions and for this reason was especially useful. By the end of the century Lorenzo de' Medici attended anti-Semitic debates, but earlier he

opposed the attempts to remove the Jews ... for he saw economic advantages in their presence. In addition, his humanist training may have instilled in Lorenzo contempt for discrimination on racial or even religious grounds. Among his circle of literate friends were men who questioned whether virtue existed solely in the Western Christian tradition and who appreciated the value of the writings of the ancient Greeks, Romans, Arabs, and Hebrews. Lorenzo himself had protected and patronized Hebrew scholars. In 1478, when a pontifical delegation went to Lorenzo hoping to work out a plan for levying taxes on Florentine Jews, Lorenzo carefully avoided compliance. ${ }^{113}$

ers in Medieval and Renaissance Italy," Journal of Economic History 60 , no. 1 (2000): $164-89$, at 173 .

111. Ibid., 164.

112. Michael Dean Crews, "From Illicit Usurers to Magnificent Statesmen: Florence's Dynamic Perceptions of Wealth, Economics and Banking from the 13th to the 15th Century" (MA thesis, San Diego State University, 2010), 60.

113. Menning, Charity and State in Late Renaissance Italy, 31. For Lorenzo's attendance at anti-Semitic debates, see eadem, "The
In short, before the late fifteenth century, the humanists and merchants in the circle of the owners of the fable books were relatively sympathetic to the Jews.

In the last few decades of the quattrocento, however, anti-Jewish sentiment in Florence hardened and intensified. Jews were seen as foreigners, and discriminatory fines and regulations increased. ${ }^{114}$ Anti-Jewish feeling, incited by such preachers as Savonarola, culminated in 1495 in the establishment of a monte di pietà (charity with low-rate loans) and the expulsion of the Jews. ${ }^{115}$ Florence was among the last Italian towns to expel its Jews; the movement began in Perugia in 1462 and continued in Orvieto in 1463, Siena in 1472, Prato in 1476, and Genoa in 1483. ${ }^{116}$ Stephen Bowd has recently demonstrated that humanists often supported anti-Semitic views, but his evidence dates largely from the end of the quattrocento. For example, after witnessing a debate between Jews and Christians that took place about 1485, Marsilio Ficino concluded that Jews lacked wisdom and that "Jewish guile is crushed and Christian truth is upheld," and in the same decade, Giovanni Pico della Mirandola's Heptaplus urged Christians to "attack" Jews who refused to convert. ${ }^{117}$ Anti-Semitism reached an "explosive level" in the late fifteenth century, ${ }^{118}$ but the fable books were produced before this wave of anti-Jewish feeling.

\section{Yiddish Prints}

After the publication of Der Edelstein in Bamberg in 1461, prints of the fable of the murdered Jew appeared next in late fifteenth-century Italy. Such prints were reproduced in multiple copies throughout the country and likely reached a wider audience. The tale appears in fable books printed in Verona in 1479, Naples in 1485, Brescia in 1487, and Venice in $1493 .{ }^{119}$ Such books also appealed to a Jewish audience, and the fable is included in the Yiddish Kuh-Bukh (Book of Cows),

Monte's 'Monte': The Early Supporters of Florence's Monte di Pietà," Sixteenth Century Journal 23, no. 4 (1992): 661-76, at 663.

114. Menning, Charity and State in Late Renaissance Italy, 32.

115. Ibid., 45.

116. Ibid., 28-29.

117. Stephen Bowd, "Death by Humanism," History Today 63, no. 8 (2013): $31-38$, at 35 .

118. Crews, "From Illicit Usurers to Magnificent Statesmen," 65.

119. Max Sander, Le livre à figures italien depuis 1467 jusqu’a 1530: essai de sa bibliographie et de son histoire (Nendeln: Kraus Reprint, 1969), 1:10, nos. 50, 52, 53; 1:13, no. 64. Another printed book included the fable of the murdered Jew: Sebastian Brant, Esopi Appologi sive Mythologi cum Quibusdam Carminum et Fabularum (Basel: J. de Pfortzheim, 1501). The fable "De iudeo et pincerna latrine" appears out of order in this edition, and it is excluded from those of 1479 and 1521. 
published in Verona in 1595 (second edition, Frankfurt, 1697). ${ }^{120}$ Derived from Boner's Der Edelstein, the text differs from it and other Christian versions primarily in its omission of all references to the Jew's wealth. A comparison of the illustrations is also revealing. The Kuh-Bukh includes four images for this fable, more than any other version, which suggests the story's importance to its Jewish audience. The first three woodcuts closely parallel illustrations in earlier books, but the final print focuses on the execution of the murderer, which was sometimes omitted previously or included only as a minor motif. For the first time, the murderer is broken on the wheel, a particularly brutal and degrading punishment. ${ }^{121}$ In addition, unlike images produced for Christians, the Yiddish woodcut shows a huge crowd witnessing the event, which must have given great satisfaction to its Jewish audiences. Jews visualized violence against their own people in a manner strikingly different from Christians. The choice of the wheel to punish the murderer and the inclusion of a huge crowd of witnesses would have expressed the Jews' longing for the just punishment of those who attacked them.

\section{Conclusions}

This essay has examined a small group of images that criticize Christian violence against Jews. Both the pillage of a Jewish home and the fable of the murdered Jew derive from historical incidents in which Jews who were protected by their king came under attack. Both narratives were composed by someone in the royal circle who wished to rebuke those guilty of the crime of lèse-majesté. If the initial impulse for these tales was class conflict between a king and his underlings, then later iterations of the fable were motivated instead by the concerns of other classes of aristocrats who wished to

120. For images in the first edition, see Diane Wolfthal, Picturing Yiddish: Gender, Identity, and Memory in the Illustrated Yiddish Books of Renaissance Italy (Leiden: Brill, 2004). For the second edition, see Eli Katz, ed. and trans., Book of Fables: The Yiddish Fable Collection of Reb Moshe Wallich, Frankfurt am Main, 1697 (Detroit: Wayne State University Press, 1994).

121. For methods of execution and their portrayal in medieval and early modern art, see Christoph Hinckeldey, ed., Justiz in alter Zeit (Rothenburg ob der Tauber: Mittelalterliches Kriminalmuseum, 1989); and Mitchell B. Merback, The Thief, the Cross, and the Wheel: Pain and the Spectacle of Punishment in Medieval and Renaissance Europe (Chicago: University of Chicago Press, 1999). Some Christians who murdered Jews were indeed executed on the wheel. See Ruth Gay, The Jews of Germany: A Historical Portrait (New Haven: Yale University Press, 1992), 64; and Dorothy Bilik, "Women Role Models in The Memoirs of Glückel of Hameln: Merchants, Matriarchs, and Mothers," in "Di froyen": Women and Yiddish; Tribute to the Past, Directions for the Future; Conference Proceedings (New York: National Council of Jewish Women, 1997), 8-11, at 10. safeguard their source of loans or were in conflict with their king or overlord or by merchants who identified with Jews in their desire to protect themselves from murderous thieves. Nevertheless, the initial conflict described in the fable between a king and his servant continued to be visualized, as in each case local concerns, those of aristocrats or merchants, superseded anti-Jewish sentiment and violence against Jews is condemned. It is noteworthy that these sympathetic portrayals of Jews appear only in secular books, not in those made for devotional ends.

In showing that Jews interpreted anti-Semitic violence quite differently from Christians, either by refraining from depicting contemporary scenes of pillage or by radically refashioning the fable, my analysis draws on the ideas of Eva Frojmovic. ${ }^{122}$ I also build on numerous scholars, most recently Sara Lipton, who explore the intersection of gender and religious identity. ${ }^{123}$ In fact, the representation of gender distinguishes the two narratives. Although Les fleurs des chroniques visualizes Christian men as aggressors and a Jewish woman as the innocent victim, in the fable of the murdered Jew all the actors are male. The portrayal of a contemporary Jewish man in a sympathetic manner forms an exception to Lipton's assertion that even though images of contemporary Jewesses are rarely stereotyped, Jewish men often are. Whereas exemplary tales whose goal was to castigate Christian sin often involve sympathetic representations of male Jews who convert in the end, the fable discussed in this article is striking precisely because it concerns a male Jew who remains Jewish, yet is still portrayed in a positive light. ${ }^{124}$

The images and texts that I have explored enable us to envision a range of possible audience responses. One reader of a fifteenth-century Tuscan manuscript removed the folio on which the fable of the murdered Jew appeared. ${ }^{125}$ This reader

122. See, for example, Eva Frojmovic, ed., Imagining the Self, Imagining the Other: Visual Representation and Jewish-Christian Dynamics in the Middle Ages and Early Modern Period (Leiden: Brill, 2002).

123. For Lipton, see note 15 above.

124. For such exempla, see Anne F. Harris, "The Performative Terms of Jewish Iconoclasm and Conversion in Two Saint Nicholas Windows at Chartres Cathedral," in Beyond the Yellow Badge: AntiJudaism and Antisemitism in Medieval and Early Modern Visual Culture, ed. Mitchell B. Merback (Leiden: Brill, 2007), 119-41, at 126, 133-35; and André Vauchez, "L'image vivante: quelques réflexions sur les fonctions des représentations iconographiques dans le domaine religieux en Occident aux derniers siècles du Moyen Âge," in Pauvres et riches: société et culture du Moyen Âge aux temps modernes; mélanges offerts à Bronislaw Geremek à l'occasion de son soixantième anniversaire (Warsaw: Wydawnictwo Naukowe, 1992), 231-41, at 233.

125. Zago, Owen, and Serwatka, "Jew and the King's Cup-Bearer," 239. The manuscript is Florence, Biblioteca Riccardiana, MS 1385.

$126:$ Gesta $\quad$ v55n1, Spring 2016 
may have wished to eliminate from the codex a sympathetic image of a Jew and the condemnation of his assailant. Yet by visualizing Jews as innocent victims of Christian aggression, medieval writers and artists opened a space in which some readers might understand that sometimes Christians wrongly assault Jews.

The epigraph of my article illustrates how this might occur textually. In his hagiography of William of Norwich, Thomas of Monmouth invents "an imaginary sketch of the trial" of the murderers of Eleazar, which begins with the Jews pleading their case before the king. Thomas has them implore, "We Jews are yours ... your very own Jew was killed. ... We do not think it right that any Christian who wants to can kill a well-behaved Jew and go unpunished."126 Even though this passage is embedded in a volume that includes an accusation of ritual murder that caused great harm to European Jewry, these eloquent and powerful words may have led some readers to wonder, however briefly, whether Jews might be

126. Thomas of Monmouth, Life and Passion of William of Norwich, 65, 67; and idem, Life and Miracles of St. William of Norwich, 99 ("In iudiciali genere coniecturalis causa," 100; "Nos iudei tui sumus ... domine rex, iudem peremptum esse contat," 102). For the rest of the quote, see note 1 above. For Thomas's text, see also Langmuir, "Thomas of Monmouth," 820-46. innocent of such crimes. ${ }^{127}$ Similarly, seeing images of an innocent Jewish woman being thrown to the ground and sexually assaulted or a Jewish man treacherously stabbed in the back might have engendered a modicum of sympathy in some medieval viewers.

All that remains of two traumatic Christian attacks on medieval Jews - the riot in Paris in 1380 and the murder of Eleazar in Norwich in 1146-are the traces left by writers and artists who interpreted the events. These traces planted seeds of sympathy for Jews, but these seeds did not take root. In part the illuminations failed to have a major impact because they were few in number and few readers saw them. Many more would have been needed to turn the tides of anti-Semitism, but this small group of images that portray innocent Jews assaulted by avaricious Christians does reveal moments when artists challenged the dominant discourse. As Miri Rubin justly observed, "In order to discover such voices one has to believe that choice is possible at all, and thus see in violence not the inevitable, spontaneous and culturally 'expected' reaction, but a choice." 128

127. For the concept of the resistant reader, see Judith Fetterley, The Resisting Reader: A Feminist Approach to American Fiction (Bloomington: Indiana University Press, 1978).

128. Rubin, Gentile Tales, 5. 